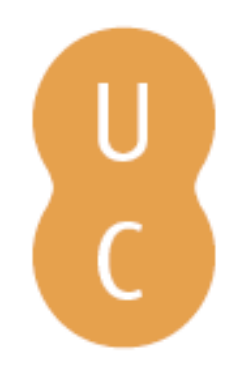

\title{
nommalina
}

\section{O magistério da história e a exemplaridade do 'grande homem': a biografia em Oliveira Martins}
Autor(es):
Catroga, Fernando
Publicado por: Imprensa da Universidade de Coimbra
URL
persistente:
URI:http://hdl.handle.net/10316.2/32581
DOI:
DOI:http://dx.doi.org/10.14195/978-989-26-0442-8_12
Accessed : $\quad$ 26-Apr-2023 15:11:24

A navegação consulta e descarregamento dos títulos inseridos nas Bibliotecas Digitais UC Digitalis, UC Pombalina e UC Impactum, pressupõem a aceitação plena e sem reservas dos Termos e Condições de Uso destas Bibliotecas Digitais, disponíveis em https://digitalis.uc.pt/pt-pt/termos.

Conforme exposto nos referidos Termos e Condições de Uso, o descarregamento de títulos de acesso restrito requer uma licença válida de autorização devendo o utilizador aceder ao(s) documento(s) a partir de um endereço de IP da instituição detentora da supramencionada licença.

Ao utilizador é apenas permitido o descarregamento para uso pessoal, pelo que o emprego do(s) título(s) descarregado(s) para outro fim, designadamente comercial, carece de autorização do respetivo autor ou editor da obra.

Na medida em que todas as obras da UC Digitalis se encontram protegidas pelo Código do Direito de Autor e Direitos Conexos e demais legislação aplicável, toda a cópia, parcial ou total, deste documento, nos casos em que é legalmente admitida, deverá conter ou fazer-se acompanhar por este aviso.

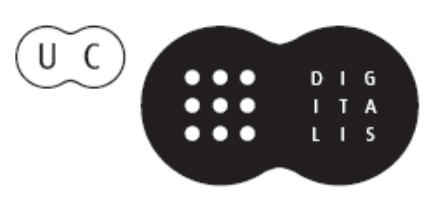


Aurelio Pérez Jiménez, Joșé Ribeiro Ferreira

e Maria do Céu Fialho

(COORdinadores)

\section{Adminiftri Principum.}

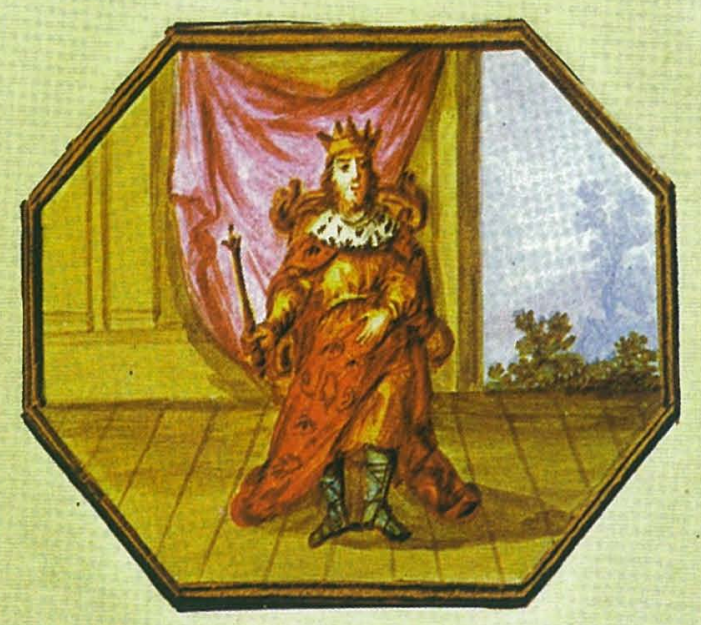

\section{EMBLEM A LIV.}

En tibi plura gerit, quàm lumina prabuit Argos Rex; Aures totidem, quin totidemó, manus. Hec opus Imperio, fidis fupplenda Minijtris, Regi bi funt aures: lumina clara, manus.

\section{- Retrato e a Biografia como estratégia de teorização política}

IMPRENSA DA UNIVERSIDADE DE COIMBRA

Universidad de MálaGa 
(Página deixada propositadamente em branco) 
Aurelio Pérez Jiménez

José RIBEIRo FERREIRA

Maria do Céu Fialho

O RETRATO LITERARIO E A BIOGRAFIA COMO ESTRATÉGIA

\section{DE}

TEORIZACCÃO POLITICA

IMPRENSA DA UNIVERSIDADE DE COIMBRA

UnIVERSIDAD DE MÁlaGa

2004 
Obra publicada com a colaboração de:

Centro de Estudos Clássicos e Humanísticos (Universidade de Coimbra)

International Plutarch Society

Primera edição, Junho de 2004

(c) IMPRENSA DA UnIVERSIDADE DE COIMBRA

(c) Área de Filología Griega. Universidad de Málaga

Coordenação editorial:

Imprensa da Universidade de Coimbra

Área de Filología Griega de la UMA

ISBN: 972-8704-25-9 (PORTUGAL)

ISBN: 84-608-0166-7 (ESPANHA)

Depósito Legal: MA-1420

Impresso em Espanha

Execução gráfica:

IMAGRAF IMPRESORES, S.A.

c/ Nabucco 14

29006 Málaga

Tfno. 952328597

Página de rosto:

"Dos Princepes Transùmptos verdadeiros": Francisco António Novaes Campos, Principe perfeito. Emblemas de D. Joâo de Solórzano. Edição fac-similada do manuscrito da Biblioteca Nacional do Rio de Janeiro oferecido ao Príncipe D. João em 1790 (Prefácio, introdução, comentário e índices por Maria Helena de Teves Costa Ureña Prieto), Instituto de Cultura e Língua Portuguesa, Lisboa, 1985, Emblema LIV, p. 114. 


\section{O MAGISTÉRIO DA HISTÓRIA E A EXEMPLARIDADE DO 'GRANDE HOMEM' A BIOGRafia EM Oliveira Martins ${ }^{*}$}

Fernando Catroga

Universidade de Coimbra

\section{I}

\section{Pressupostos clássicos do preceito historia magistra vitae}

Para muitos estudiosos, mais do que uma fractura, a metafísica grega terá conferido uma maior racionalização ao cariz ahistórico da mentalidade arcaica. O tempo continuou a ser vivido como uma manifestação fenomenal, que diversifica e degrada, isto é, como uma imagem onticamente pobre do Modelo - o Ser uno, eterno e imóvel. Dito de outro modo: o tempo do universo seria, tão-só, como afirmou Platão no Timeu, a imagem móvel da eternidade, porque identificado com o movimento dos corpos celestes. Pelo que a sua fenomenologia objectivava o mundo visível (mundo de apareceres e de aparências), enquanto o invisível era assimilado à substância eterna, à qual seria inaplicável qualquer expressão que pudesse sugerir mudança.

Só o que era natural tinha o estatuto de eternidade. Se o fabricado pelo homem ainda possuía esta característica - dado que colhia a sua matéria da natureza -, o

* Este artigo sintetiza e dá uma nova articulação a ideias já expandidas em Fernando Catroga, Caminhos do fim da história, Coimbra, Quarteto Editora, 2003, pp. 1-113, e em "História e ciências sociais em Oliveira Martins", in Luís Reis Torgal et al., História da história em Portugal. Sécs. XIX - XX, Lisboa, Círculo de Leitores, 1996, pp. 117-159. No entanto, a sua primeira parte é inédita.

A. Pérez Jiménez, J. Ribeiro Ferreira, Maria do Céu Fialho (edd), O retrato literário e a biografia como estratégia de teorização política, Coimbra-Málaga, 2004, pp. 243-288. 
que resultava da sua praxis e da sua fala (lexis) seria precário, pois expressava a individualidade de uma existência que, com tais obras e feitos, se subtraía à eternidade do género, mas que, sem a mediação de práticas anamnésicas, ficaria condenada à finitude e à morte (Hannah Arendt, 1968).

Ter presente todos estes argumentos será condição necessária para que não se caia em interpretações anacrónicas, como a de se pensar que - mesmo nos autores que mais se aproximaram do antropocentrismo (os Sofistas, por exemplo) - os gregos (e os romanos) podem ser elevados a uma espécie de precursores do historicismo moderno e, em particular, do seu princípio segundo o qual é o homem quem "faz" a história.

Importa assim pesar a pertinência, ou não, destas hipóteses: não terão os ideais gregos de verdade (como os de bem e de belo), e a sua correlativa concepção geométrica do cosmos, sido pouco sensíveis a um tipo de reflexão a que, mais tarde, se chamará "filosofia da história", independentemente das ideações sobre os processos de indagar o passado que se encontram nos textos clássicos (Heródoto, Tucídides, Políbio, Cícero)? Sujeita à tikê (destino, fado), mas ameaçada pela hybris (desmesura), a assunção da história como antropodiceia não significaria fazer do tempo dos homens uma obra supra-sensível, logo, com características análogas às do próprio cosmos? Em suma: não seriam estas premissas incompatíveis com o núcleo forte do substancialismo metafísico grego? Responder a estas questões, ainda que de um modo necessariamente sintético, será uma boa base para se debater a questão concernente às semelhanças e às diferenças que terão existido entre esta perspectiva $\mathrm{e}$ as ideias que nortearam o aparecimento da história (sobretudo com Heródoto) como género literário.

\section{Narrar o que se viu}

Desde logo se impõe destacar esta nota fundamental: como Aristóteles assinalou, só o geral, o fixo e o necessário poderiam ser objecto de conhecimento (episteme): "Para quem trate de investigar o que é o contingente, resultará evidente que não haja uma ciência do contingente" ( Aristóteles, Metafísica, XI, 8, 1064). Pelo que a história (como historiografia) seria epistemologicamente mais pobre do que a própria poesia, cabendo à filosofia, saber dos saberes, o lugar cimeiro. Isto é, e como escreveu o Estagirita, "não é ofício do poeta narrar o que aconteceu; é, sim, o de representar o que poderia acontecer: o que é possível segundo a verosimilhança e a necessidade. Com efeito, não diferem o historiador e o poeta, por escreverem verso ou prosa (pois que bem poderiam ser postas em verso as obras de Heródoto e nem por isso deixariam de ser história, se fossem em verso o que eram em prosa) diferem, sim, em que diz um as coisas que sucederam, e outro as que poderiam 
suceder. Por isso a poesia é algo de mais filosófico e mais sério do que a história, pois refere aquela principalmente o universal, e esta, o particular. Por 'referir-se ao universal' entendo eu atribuir a um indivíduo de determinada natureza pensamentos e acções que por liame de necessidade e de verosimilhança, convêm a tal natureza; e ao universal, assim entendido, visa a poesia, ainda que dê nomes aos seus personagens; particular, pelo contrário, é o que fez Alcibíades ou o que lhe aconteceu" (Aristóteles, Poética, 1451 a, 36; 1451 b, 10).

A citação foi longa, mas impunha-se para ilustrar o que atrás se afirmou: na hierarquia dos saberes, mesmo a poesia era superior à história; esta, limitada à descrição do que se move e aparece, só podia emitir a mera opinião (doxa), narrando, portanto, uma colecção de factos particulares, enquanto aquela revelava capacidade para formular juízos mais universais e sem precisar de estabelecer relações miméticas entre a narrativa e a realidade narrada.

Assinalar esta depreciação é fundamental para se entender o elo existente entre a historiografia e a metafísica gregas, começando por lembrar que aquela surgiu sob o signo do olhar e, logo, da percepção. Por exemplo, para Heródoto de Halicarnasso, considerado o "pai da história", as investigações (historie, apodexis) mais credíveis eram as que decorriam da observação directa (opsis), e não tanto das fontes, ou mesmo das informações alheias, aceites como meras notícias que o historiador-investigador devia registar, mas em que não era obrigado a crer. E esta atitude metódica decorria da própria semântica da palavra que a designava.

Com efeito, tal como eidenai (conhecer), também o vocábulo historia deriva de $i d$-, ver, e histor significava, originariamente, testemunha ocular, e, posteriormente, aquele que examina testemunhas e obtém a verdade, através da indagação. Por conseguinte, historein refere-se tanto a testemunhar como a investigar, acepções que se tornarão mais claras a partir desta regra, consignada no Gutapathe-Brahamana: discutem dois homens, dizendo um "eu viu-o" e o outro "eu ouviu-o". É certo que não se negava valor informativo àquilo que tinha sido ouvido. Porém, ele era supletivo face ao da vista e requeria uma maior vigilância crítica. De qualquer modo, no privilégio dado à visão radicava o poder que o histor tinha para derimir as controvérsias, capacidade que o elevava ao papel de árbitro, de juiz. Por sua vez, o termo dikê (= justiça) tem por origem (ao contrário de themis, que denota os fundamentos sacrais do direito positivo, a começar pela sua administração no interior do grupo familiar) o radical deik(mostrar); logo, dikê remetia para justiça, com o sentido de mostrar com autoridade, mostrar o que deve ser; e este significado também se encontra no composto latino iudex, em que deik- aparece unido a ius: só o juiz pode dizer ius (Hannah Arendt, 1968; G. Maramao, 1989; E. Benveniste, 1969). 
Verifica-se, assim, que as etimologias de histor, de juiz-testemunho e de justiça confirmam o relevo dado às evidências da visão. $\mathrm{E}$ a sua raiz permite ainda perceber por que é que, para os gregos, este tipo de "histórias" descrevia, dominantemente, o passado recente: especialistas em procedimentos judiciais, o trabalho dos historiadores incidia, sobretudo, na acribia da observação directa, ou, segundo o modelo hipocrático aplicado na arte médica, na depuração do testemunho oral (Tucídides). Frise-se que, na própria organização textual, expressões como "eu vi" não escondem o sujeito da enunciação, isto é, explicitam a intervenção do narrador no seu relato, doando-lhe autoridade e elevando o "eu vi" (ou o "eu digo") a garante de verdade. Também por isso, quando a retrospectiva vai mais longe e trata de tempos mais antigos e, portanto, não vistos, ela acaba por dar guarida (como se nota em Heródoto) a relatos míticos e tradicionais (François Châtelet, 1978).

Chegados a este ponto, será altura para perguntar se esta historiografia rompeu, por inteiro, com a mitologia (o que parece não ter acontecido com Heródoto), e se o seu modo de contar não terá dependido da passagem da narração oral para a escrita, trânsito que fomentou uma maior racionalidade. É que, enquanto a primeira procurava convencer, suscitando, no ouvinte, o espanto e o sublime, com a prosa, o trabalho de convencimento do leitor tinha de assentar em juízos argumentativos, por mais excepcionais e exemplares que fossem os acontecimentos narrados. Ora, não há dúvida que, a partir dos séculos V e IV a.C., diminuiu a credibilidade do mito e aumentou a crença nas capacidades da razão inquiridora, como se verifica na sofistica e, principalmente, no diálogo socrático. Será assim importante levantar a hipótese de que, por exemplo, entre Tucídides - com as suas preocupações com a prova (autopsia) - e Heródoto, a diferença não está tanto na circunstância de ambos não procurarem a verdade, mas residir na finalidade dos seus discursos: o "escrever para sempre" (Tucídides) e o escrever para se declamar perante um público (objectivo ainda patente nos textos de Heródoto) põem em acção estratégias diferentes: em Tucídides, a acribia (a conformidade com os factos) excluía os "dizeres" não comprovados; em Heródoto, tentava-se prender a atenção do receptor, contando o que se viu, em ordem a gerar-se prazer através da sugestão da mimesis (Jorge Lozano, 1994).

\section{A imutabilidade do Ser e a exemplaridade da história}

Como se assinalou, a sensibilidade grega, conquanto não fosse indiferente aos fenómenos da mudança (daí, o "nascimento da história"), tinha uma obsessão pelo imutável. Mesmo o seu pensador mais "dialéctico" (Heraclito), não só buscou um fundamento omnipresente para o devir, como defendeu que o movimento cósmico culminaria, tal como nas cosmogonias míticas, na deflagração universal (ekpyrosis). 
Por outro lado, não se deve esquecer que, em termos metafísicos, a corrupção era subordinada ao causalismo formal e final, pois, como se sabe, para o grego, importava captar o que permanece, que especifica, dá configuração e determina a finalidade perseguida por aquilo que devém. O fim seria, portanto, a meta a que os entes particulares aspirariam, consumando-a num ciclo finito, indefinidamente repetido e repetível, sempre diferente e sempre igual, num processo em que o omega seria a explicitação necessária do alfa.

Será pertinente perguntar, porém, se a metafísica não tinha como pano de fundo a sobrevivência de concepções míticas acerca do eterno retorno. E, aos que acham excessiva esta tese, importa lembrar que a caracterização do tempo como um círculo também se encontra em Aristóteles, para quem, a par da eternidade do universo, "o tempo parece ser o movimento da esfera, porque este movimento é o que mede os outros movimentos e mede também o tempo .... e também o tempo parece ser uma espécie de círculo .... pelo que dizer que as coisas geradas constituem um círculo, é dizer que há um círculo de tempo" (Aristóteles, Problemas, XVII, 3916 a).

De acordo com esta ontologia, compreender-se-ão melhor os limites do valor ôntico dos acontecimentos narrados pelos historiadores. Sublinhe-se que, para Aristóteles, todas as criaturas vivas, incluindo o homem (pelo menos enquanto género), estavam incluídas numa natureza sempre presente e, por conseguinte, seriam dotadas de imortalidade ( $D$ a alma, 425b13). Mediante o ciclo repetitivo da vida, a natureza assegurava, "para as coisas que nascem e morrem, o mesmo tipo de eternidade para as coisas que são e não mudam". Todavia, do ponto de vista da praxis e da capacidade comunicativa do homem, este, ao autonomizar-se do determinismo da espécie, afirmava-se como um indivíduo, condição que ditava a sua finitude. Por palavras de Hannah Arendt, que estamos a seguir, "a mortalidade humana repousa no facto de que a vida individual, um bios com uma história de vida identificável do nascimento à morte, emerge da vida biológica, dzoe. Essa vida individual distingue-se de todas as outras coisas pelo curso rectilíneo do seu movimento, que, por assim dizer, secciona transversalmente os movimentos circulares da vida "biológica"' (Hannah Arendt, 1968). E a praxis veio reforçar esta autonomização.

A especificidade do novo discurso historiográfico terá residido na sensibilidade que este revelou em relação à face concreta da vida humana. De certo modo, ela prolongava o protesto que, desde a construção de monumentos e da transmissão geracional - possibilitada pela oralidade e pela poesia escrita, - procurava remediar a inexorável queda no esquecimento das obras e dos feitos dos homens. Daí que a sua temática tenha incidido, principalmente, sobre situações únicas, feitos ou eventos que "interrompem o movimento circular da vida diária, no mesmo sentido em que o bios 
rectilinear dos mortais interrompe o movimento circular da vida biológica. $\mathrm{O}$ tema da história são essas interrupções - o extraordinário, em outras palavras". Mas, se foi assim, poder-se-á concluir, sem mais, que " os grandes feitos e obras de que são capazes os mortais, e que constituem o tema da narrativa histórica, não são vistos como parte, quer de uma totalidade ou de um processo abrangente", porque "a ênfase recai sempre em situações únicas e rasgos isolados" (Hannah Arendt, 1968)?

Se, com esta afirmação, se pretende sustentar que os gregos não postulavam a existência de qualquer logos imanente aos eventos humanos, que se explicitasse num finalismo sobredeterminado pela ideia de futuro, a tese é aceitável. Todavia, convém frisar que o uso da exemplaridade narrada pelos historiadores obedecia a propósitos de convencimento, exigência que levava à inserção dos acontecimentos em totalidades finitas e sem a existência de qualquer pretensa lógica auto-suficiente a comandar a irreversibilidade do devir universal, como será apanágio das futuras "filosofias da história".

Como alguma história da historiografia clássica tem sublinhado, comummente, as "investigações" seleccionavam conjuntos limitados de factos que se sucederam no tempo, mas que só eram explicáveis através de uma ordenação que lhes conferia forma, integrando-os num todo coerente; contra o caos, a narração construía uma totalidade, conquanto finita e fechada, que, tal como na tragédia, era tecida por uma trama com um princípio, um centro e uma conclusão. Deste modo, explica-se que os historiadores gregos (e romanos), mesmo os mais factualistas, não se preocupassem com a descrição dos eventos tal qual eles aconteceram; estes só ganhavam sentido desde que incluídos num enredo. Com isso, e ao invés do que pensou Aristóteles, o discurso historiográfico ultrapassava o particular (as situações únicas e as acções individuais), pois a verdade do narrado não estaria tanto na adequação dos enunciados à realidade, mas mais na sua correlação e correspondência com um modelo de virtudes - pressuposto que muitos, como Plutarco, não deixarão de explorar -, ou com uma teoria, principalmente com aquela que apontava para a existência de oscilações cíclicas nos negócios humanos (Políbio), ou a que pressupunha a identidade da natureza humana (Tucídides). Em síntese: a narração, apesar do seu aparente cariz doxográfico, tinha subjacente um ideal de verdade que era sinónimo de construção de conjuntos harmoniosos, em consonância com o que também se encontrava objectivado no ideal epistémico e estético da Hélade.

\section{A memória e o magistério da história}

É dentro destes parâmetros que aqui se discute a função social que os gregos atribuíam à escrita da história. Esta devia ser bela e pragmática, dado que os ritmos da 
vida poderiam vir a repetir-se. Mas, enquanto "arte de memória", e protesto contra a mortalidade a que estavam sujeitos os dizeres e as obras humanas, ela também era monumento, isto é, um garante da vitória sobre o esquecimento. E estas funções já se encontram presentes em Heródoto, autor que, com intenções de imparcialidade, escreveu as suas Histórias (Liv. 1. ${ }^{\circ}, 1.1$ ) "para que os feitos dos homens não desvaneçam com o tempo, nem fiquem sem renome as grandes empresas, realizadas quer pelos Helenos quer pelos Bárbaros".

Sem ambiguidades, colocava-as sob a tutela de Mnemosyne. Compreende-se. É que, como afirmou um sábio grego, "os homens morrem, porque não são capazes de juntar o começo e o fim"; e só Mnemosyne, a deusa da memória e, consequentemente, a mãe de todas as musas, podia ligar o que os indivíduos foram, com o que são e com o que serão (Fernando Catroga, 2001). Através da cristalização do que se viu e indagou, possibilitada pela escrita, tentava-se vencer a amnésia a que, entregues a si mesmos, estavam condenados os feitos que marcam a individualidade do homem. A escrita da história propunha-se derrotar a amnésia produzida pela corrupção do tempo e pela índole não natural das acções especificamente humanas, logo, pela biografia dos indivíduos, concretizada num tempo rectilíneo mas finito, embora mergulhada no tempo cíclico ou eterno, próprio da natureza e do género. Por outras palavras: só a fama, garantida pela memória, poderia vencer a precariedade de tudo o que resultava da praxis, aproximando-se da eternidade das coisas naturais.

Neste horizonte, não espanta a vocação pedagógica (e cívica) da nova literatura historiográfica: ela contava o que já foi, com o fito de lembrar, à luz dos ritmos cíclicos, ou da repetição do que é característico na natureza humana, o que poderá vir a acontecer, mostrando que, não obstante ao homem só ser dada uma pequena margem para fugir ao destino, a tikê não conduziria ao fatalismo absoluto, e o fado, que preside à vida humana, só teria um poder destruidor, porque, tal como se mostrava na tragédia, o homem é habitualmente cego em relação aos seus ditames, não sabendo formular opiniões correctas que, sem se cair na hybris, permitam evitar os seus golpes decisivos (Manuel Benevides Lucas, 1994).

O ritmo do cosmos, a raiz ahistórica da natureza humana e a fama (perpetuada pela escrita) são, assim, as traves-mestras que devem ser invocadas para se entender melhor o consabido preceito greco-romano (Tucídides, Políbio, Cícero) segundo o qual a história é mestra da vida (historia magistra vitae): "Historia vero testis temporum, lux veritatis, vita memoriae, magistra vitae, nuntia vetustatis, qua voce alia nisi oratoris immortalitati comendatur" (Cícero, De oratore, II, c. 9, 36 e c. 12, 51). A tarefa directora que Cícero adjudicava à história (ou melhor, à história como 
arte) tinha em vista obter efeitos análogos aos da oratória, fornecendo a esta, com imparcialidade, uma colecção de exemplos pedagógicos (plena exemplorum est historia) (Reinhart Koselleck, 1993). Para isso, e tal como outras formas de evitar a queda no esquecimento, a historiografia era também garante de transmissibilidade. $\mathrm{O}$ que dá sentido ao facto de ela ter sido qualificada, não só como verdadeiro testemunho do tempo e como discurso aletológico ("lux veritatis"), mas também como "vita memoriae". No fundo, o escritor romano sublinhava os liames estreitos que enlaçavam estres três níveis, dando expressão aos ensinamentos de Heródoto e ao que já Tucídides escrevera acerca da utilidade da sua História da Guerra do Peloponeso: partindo do pressuposto de que a natureza humana é o grande motor da história, o registo daquele evento seria uma aquisição para sempre, pois a "ideia-tipo" (Raymond Aron) que estruturava a obra continuaria a valer, porque, independentemente dos indivíduos concretos (vivos ou vindouros), a natureza humana permaneceria sempre a mesma. De facto, o seu livro não se limitava a descrever acontecimentos do século V a.C.; tinha igualmente a finalidade de servir de modelo para a compreensão dos que, no futuro, e em virtude do inalterável carácter humano, virão a ser semelhantes ou análogos.

A cristianização das consciências, com as suas promessas de cariz sotereológico e escatológico, assentes na predominância da fé sobre a razão e, consequentemente, da verdade revelada sobre a inquirida, interiorizou um entendimento providencialista da história, justificado à luz da superioridade da Cidade de Deus sobre a Cidade dos Homens (Santo Agostinho). Assim, entende-se que, no plano historiográfico, a concepção greco-romana, segundo a qual a investigação do passado tinha uma função pragmática, recebesse, agora, uma justificação dominantemente metafísico-religiosa. Por isso, também não se dava continuidade ao preceito herodotiano que baseava a validade do narrado no "visto", e mesmo no "ouvido", já que se ousava contar o que ultrapassava esses limites, desde que pudesse ser afiançado pela crença e pela autoridade da Igreja; portanto, o passado só podia ser objecto historiográfico se fosse apreendido através da fé, o que colocava o texto sagrado como exclusivo paradigma de explicação do sentido do tempo. E o pretérito, objecto de fé, contrastava com o presente, objecto de conhecimento. Consequentemente, este horizonte torna compreensível que historiadores cristãos aceitassem, sem vigilância crítica, as narrações fornecidas pela tradição e garantidas por uma autoridade reconhecida (igreja, monarquia, universidade), ou pela santidade e posição social de quem as transmitia. Esta credulidade levava-os a "falar do passado, referido nesses relatos, como se eles próprios o tivessem vivido" (K. Pomian, 1984).

Tais pressupostos ajudam a inteligir melhor as características essenciais que enformaram a historiografia medieval, a saber: a periodização do tempo histórico, 
feita segundo o modelo cristológico; a sua função catequética; a sua ultrapassagem dos particularismos (a unicidade de Deus fundamentava, numa cristianização do velho estoicismo, uma perspectiva universalista de humanidade); a sua escrita, encarada como um trabalho anónimo e geracionalmente contínuo (como tem sido assinalado, não se fazia distinção entre as noções de historiógrafo e de cronógrafo, bem como, quanto aos géneros, entre anais, crónicas e histórias); a inexistência de uma consciência autoral, característica que explica a índole colectiva de muitos textos historiográficos da época e que relativiza as posteriores acusações de plagiato; e, por fim, a ordenação das idades e acontecimentos de acordo com a justificação providencialista, bem como o seu temário dominantemente apologético e hagiográfico (R. Collingwood, s. d.; George Gooch, 1977). Neste contexto, o magistério das narrativas já não visava produzir efeitos de índole ético-cívica; a exemplaridade enaltecida só tinha sentido desde que fosse de conteúdo religioso e convidasse à imitação das vidas virtuosas, tendo em vista a salvação das almas.

\section{II}

\section{A necessidade histórica e a acção dos indivíduos}

Na modernidade, a comparação de pensadores que procuraram teorizar uma nova visão do tempo histórico, como Voltaire, Lessing, Turgot, Condorcet, Kant, Schiller, Schelling, Hegel e seus continuadores, permite captar, nas suas diferenças, a existência de um conjunto de ideias comuns sobre a estruturação do sentido da evolução humana: a suposição de que aquele só seria conhecido quando a humanidade fosse perspectivada como uma totalidade em devir; a crença na existência de uma ordem ideal subjacente à história empírica (Vico), ou melhor, na racionalidade do real e na faculdade de a razão a esclarecer, iluminando o aperfeiçoamento humano; o princípio à luz do qual a diacronia das sociedades é fruto de antíteses, intrínsecas ao "sujeitomotor" imanente da história, que se desenrolam de um modo objectivo, universal e necessário; a fé na vocação perfectível e progressiva da humanidade. Por sua vez, todas elas tenderam a descrever esse percurso como um caminhar do Oriente para o Ocidente, viagem apresentada como uma luta para que a história passasse do reino da necessidade para o da liberdade, com um desfecho eurocêntrico. É que a Europa seria não só o lugar da definitiva revelação da verdade, mas também o agente da assunção da história como história universal. 


\section{O sentido da inteligibilidade da história}

Para demonstrarem tudo isto, as filosofias da história da modernidade procuraram ultrapassar o entendimento dos fenómenos humanos em termos de explicações mecanicistas, não obstante compartilharem, com os novos cientistas da natureza (a física, sobretudo), uma análoga convicção acerca da inteligibilidade do mundo. Recorde-se que a leitura sub specie machinae só funcionava nos quadros de uma natureza sujeita à repetição e a explicações baseadas na causalidade material e eficiente, logo, despidas de qualquer teleologismo. A natureza (física, animal, humana) ainda não era a resultante de um processo evolutivo (como o será para Lamarck e Darwin), mas era caracterizada em termos de imutabilidade, eternidade e constância. Porém, a história começava a ser valorizada como o resultado da vitória da liberdade contra o "ordenamento mecânico" da natureza, e o homem a ser visto como um ser racional, livre e eminentemente prático. E esta antropologia era fruto da expropriação imanentista do Logos divino inscrito em cada indivíduo, operação bem patente, desde Descartes, nas filosofias do cogito. Assim sendo, entende-se que, para Kant (tal como para Voltaire, Lessing, Turgot, Schiller, Condorcet, Hegel, Marx, Comte, etc.), a história fosse um processo, não só evolutivo, mas também finalístico, verificação que confirma esta hipótese: a historicidade só pôde ser pensada no quadro de uma episteme alicerçada no divórcio entre o sujeito e o mundo físico (iniciado por Descartes e praticado pela ciência moderna) e na paulatina subordinação da leitura da natureza à experiência histórica do homem.

Tanto uma posição como outra ajudaram a romper com as representações cíclicas, passando o presente a ser vivido como uma permanente actividade de preenchimento do tempo, praxis em que o homem devia agir "como se" a finalidade ético-racional - que a priori ele pode encontrar quando se eleva a uma posição transcendental (Kant) - estivesse inscrita na ordem natural das coisas. Mas, esta atitude também convidava a que este tipo de teleologismo sofresse uma maior ontologicização, linha já visível na lição de Schiller, subordinada ao tema $O$ que significa e com que fim se estuda história universal (1785), e que o idealismo objectivo alemão e as suas posteriores inversões materialistas acentuarão (J. Ch. Friedrich von Schiller, 1991; Rudolf Malter, 1991).

Explica-se agora melhor por que é que a substantivação da humanidade e da história caminhou a par com a entificação da ideia de progresso. Esta última tendeu mesmo a confundir-se com o grande rio da história, fundindo no seu leito correntes distintas, mas que nele convergiam, a saber: a secularização do milenarismo de matriz judaico-cristã; o optimismo epistemológico e histórico, enraizado nas novas ciências 
e nos seus efeitos sociais; a secularização dos fundamentos da sociedade e do poder, expressa nas diversas teorias do contrato social (Hobbes, Locke, Rousseau, Kant), as quais, ao proporem um modelo de inteligibilidade, fixavam, igualmente, um antes (estado da natureza) e um depois, definido como um campo criado pela determinação da vontade dos homens. E todos estes factores, conjugados com o princípio clássico, segundo o qual só há conhecimento do geral, não deixaram de reforçar o fundo prometeico que insuflava a mundividência moderna. É assim lógico que as núpcias entre a ideia de humanidade e a de progresso se tenham selado no reconhecimento da história como uma realidade dinâmica, que arrastava, não uma parte ou faceta, mas o espírito humano como um todo evoluente, devido à sua infinita potencialidade de aperfeiçoamento (G. Marramao, 1989; Stéphane Mosès, 1992).

No entanto, a credibilização desta ideia não deixou de operar uma alteração significativa no recurso à velha analogia - e à correspondente tradução metafórica de cariz organicista - que, desde pelo menos Santo Agostinho, passando por Vico, apresentava a periodização do itinerário da humanidade como um trilho similar ao percorrido pelos seres vivos. Mas, se esta comparação parecia incontroversa, quando se acreditava que a humanidade era finita - isto é, tinha nascido, crescido, alcançado o seu apogeu, estaria decadente e iria morrer -, a ideia de progresso (mesmo quando alguns correctivos menos optimistas lhe são introduzidos) exigia o fomento da crença na infinitude e amortalidade da humanidade.

Apesar da pressuposição de uma expectativa aberta e da recusa do encerramento da história (particularmente enfatizada por Kant), ter-se-á sempre de perguntar se a indicação de uma meta futura, caracterizada como "idade", "estádio" ou mesmo como "reino" (Reich) - numa reactualização secularizada da tradição messiânica -, e avaliada como fruto de um sujeito colectivo (espírito do mundo, espírito da humanidade, luta de classes, luta de raças), e não com o somatório da acção dos indivíduos, também não supunha, aprioristicamente, um focus imaginarius, numa projecção, feita no presente, de um "algures" que envolvia o ordenamento (e o julgamento), tanto do que já aconteceu como do que virá a acontecer. E, se o sistema de Hegel só era lógico em função da sua circularidade (que a dialéctica subsumia) - pois o fim seria a explicitação (e a explicação) da origem -, duvida-se que as concepções mais prospectivas (que não rompiam com o quadro do historicismo, ao contrário, por exemplo, do que acontecia com as críticas feitas, entre outros, por Herbart, Adolfo Trendelenburg e, sobretudo, por Kierkegaard e Nietzsche) também fossem capazes de reconhecer o novo, isto é, algo que não se cingisse a confirmar a verdade que elas mesmas prognosticavam. É que, apesar da profissão de fé na irreversibilidade do tempo, esta insensibilidade era inerente a todo o modo necessitarista e teleológico de conceber o processo 
histórico, limitação que acabava por garantir uma nova face (mesmo quando encoberta) da máxima clássica: historia magistra vitae.

\section{A historia magistra vitae no horizonte historicista moderno}

Entende-se. Sem a implicação recíproca entre o alfa e o omega seria difícil credibilizar a coerência interna do percurso, pelo que Kojève tinha razão, ao concluir, na sua Introduction à la lecture de Hegel, que "a filosofia da história - e tanto mais a filosofia hegeliana, o 'sistema' - só seria possível se a história tivesse terminado" (Kojève, 1947). Ora, se esta asserção é válida quando se acredita que a consumação já começou, também o será quando ela é situada num por-vir programado.

Em toda esta lógica, a sucessão é dita por um discurso manifesto baseado na relação de causa a efeito, ou melhor, de antecedente a consequente, na qual não haveria lugar para o acaso. De facto, as filosofias da história não só contestavam a insondável intervenção de Deus - elas compaginavam-se melhor com o deísmo e com o panteísmo -, mas também rejeitavam o papel nuclear da contingência na determinação dos acontecimentos (Sílvio Lima, 1958). Se, para as teorias providencialistas, aquela não passava de um disfarce da vontade divina, para os pensadores modernos (David Hume, Laplace, por exemplo), o acaso consistia numa simples designação, usada para velar a ignorância (mas que o progresso dos conhecimentos iria colmatar), ou, então, numa manifestação fenomenológica, inteligível desde que integrada no necessitarismo, colectivo e anónimo nas suas traduções históricas concretas, que comandaria a evolução global da humanidade. E, mesmo um pensador como Cournot, que procurou relevar o acaso (na explicação dos fenómenos naturais e sociais), recorreu a argumentos epistemológicos (cálculo das probabilidades) e históricos, para mostrar que, depois de ter partido de uma fase a ele subordinado, e de ter percorrido um período intermédio, em que a necessidade e o acaso se conciliaram, o devir estaria a entrar no seu estádio terminal, no qual a primeira subsumiria o segundo.

Bem vistas as coisas, mesmo quando o elo entre os antecedentes e os consequentes se restringia ao causalismo material e eficiente (como sucedia, em boa parte, no discurso historiográfico), não se pode esquecer que, dada a índole retrospectiva e universalista das filosofias da história - elas liam o passado a partir de ideias, valores e interesses do presente -, todos os eventos eram transformados em meios, tendo em vista a realização de um fim. Neste contexto, indivíduos e povos mais não seriam que instrumentos de que a lógica da história se servia para depois os aniquilar, secundarizar e ultrapassar. Dir-se-ia que elas punham o efeito como causa de suas causas, ilação que permite concluir que os seus intuitos de previsibilidade constituíam, em última análise, uma espécie de "previsão ao contrário" 
(Schlegel). Deste modo, o velho preceito ciceroniano historia magistra vitae tinha futuro, embora se esteja perante uma mundividência que parece situar-se nos antípodas dos seus fundamentos clássicos: a visão cíclica do tempo e a crença no cariz ahistórico da natureza humana. Ora, tal parecia não ocorrer na modernidade com a sua visão de tempo irreversível. De facto, se nada se repete, que utilidade poderiam ter as lições do passado? A resposta, na prática, não foi negativa. É que as filosofias da história, em particular as de pendor mais metafísico, acabavam por conceber o devir como uma actualização de uma potência - o seu "sujeito" ou o "motor" - que, apesar de mudar, manter-se-ia sempre idêntico a si mesmo. Assim sendo, o omega não passaria da explicitação plena do princípio, modo de dizer que, afinal, a irreversibilidade proclamada se movia nos limites de uma concepção essencialista e circular do tempo, pressuposto que, na Antiguidade, tinha justificado, embora com outros argumentos e objectivos, o magistério das lições do passado.

Em termos epistémicos, a legitimação, quer da coerência interna das grandes explicações sobre o sentido do tempo, quer do saber historiográfico propriamente dito, relevava as relações entre antecedentes e consequentes. $O$ que se entende, dado que não seria convincente explicar a sequência do eixo temporal a partir do efeito, que elas mesmas procuravam demonstrar. Daí, a versão moderna e historicista da asserção ciceroniana, muitas vezes camuflada sob as vestes da previsão, pois as teorias da história dos filósofos, tal como as dos historiadores, continuarão a defender a importância de se explicar o passado, a fim de melhor se compreender o presente e se transformar o futuro.

Em síntese: a evolução histórica estaria numa "idade" que permitia distinguir o verdadeiro "conhecimento especulativo do futuro" das previsões parcelares e particulares. Frise-se que, se Kant, na sua Antropologia em sentido pragmático (§35), separou o pressentimento (praesensio) da presunção (praesagitio), também Schelling, nas várias versões $(1811,1813,1815)$ da introdução ao incabado ensaio Die Weltalter, alertou para o facto de as três dimensões do tempo implicarem formas diferentes de apreensão e de linguagem (Schelling, 2002): o passado pode ser sabido e narrado; o presente, conhecido e exposto; mas, o futuro, somente pressentido [geahndet] e profetizado [geweissagt]. Cieszkowski foi mais longe, ao sustentar a necessidade de se não confundir o "deciframento do futuro" (praesagium) com o seu saber prévio (praescientia) (August von Cieszkowski, 2002). Explica-se. Em função do princípio de que só pode haver conhecimento do geral, também à historiosofia não interessava adivinhar este ou aquele aspecto particular, mas inteligir a verdadeira natureza humana, em ordem a iluminar a lei do seu progresso, quer na sua efectuação no passado, quer no que respeita às suas relações com o futuro. 
Por sua vez, as alternativas cientistas ao modo metafísico de justificar o sentido do tempo - teorizadas pelo pensamento social do século XIX - estavam eivadas de uma análoga intenção de presciência, e tinham a vantagem de dar uma ainda maior visibilidade à "vontade de poder" da episteme moderna, já sintetizada por Francis Bacon no célebre aforismo: saber para prever, prever para prover. Montesquieu (De l'Esprit des lois, 1748) não andou longe deste objectivo, mormente quando recorreu a modelos físicos e ao causalismo usado nas ciências da natureza para tentar explicar, em termos deterministas, a relação (a lei) entre os fenómenos sociais, visando a previsão. Todavia, antes de A. Comte, foi Condorcet quem melhor expressou o intento de se unificar a metodologia das ciências naturais com as das ciências sociais, condição fundamental para que estas conquistassem a previsibilidade que havia feito o prestígio das primeiras. É que, segundo ele, "se o homem pode predizer, com segurança quase total, os fenómenos cujas leis conhece; se, mesmo quando as desconhece, pode, com base na experiência do passado, prever, com uma grande probabilidade, os acontecimentos do futuro; porquê encarar como uma empresa quimérica traçar, com alguma verosimilhança, o quadro dos destinos futuros da espécie humana, segundo os resultados da sua história? O único fundamento da crença nas ciências naturais é a ideia de que as leis gerais, conhecidas ou não, que regem os fenómenos do universo, são necessárias e constantes; e por que razão este princípio havia de ser menos verdadeiro para o desenvolvimento das faculdades intelectuais e morais do homem do que para as outras operações da natureza?" (Condorcet, 1933).

A busca dos mesmos "fundamentos de crença" pode ser encontrada nas várias propostas que, no século XIX, darão vida aos imaginários de inspiração socialista, assim como às múltiplas tentativas para justificar a emergência da ciência social: a "fisiologia social" em Saint-Simon; a "sociologia" em Comte; o "materialismo histórico" em Marx. É certo que estas propostas se distinguiam entre si, tanto nos seus fundamentos como nos seus objectivos sociais, e as que proclamavam um cariz mais cientista acusavam as restantes de serem metafísicas ou utópicas. Todavia, a todas é aplicável o programa formulado por Buchez: fazer da história uma ciência, apta - em analogia, aliás, com a capacidade das filosofias da história - para prever o futuro social da espécie humana, na sua livre actividade ( $\mathrm{Ph}$. J. Buchez, 1833). E o desiderato de A. Comte - numa versão mais conservadora - é semelhante, pois tentou demonstrar que a sociologia tinha por finalidade última concretizar a máxima baconiana. Modo de defender que a vocação da nova ciência social, legitimada através da célebre lei dos três estados, desaguaria em técnica. E a "engenharia social" destes projectos, tanto podia servir para reproduzir o mundo histórico tal qual ele existia (era essa a intenção de Comte), como para criticá-lo, para o revolu- 
cionar. Consequentemente, é lícito concluir que o optimismo moderno se baseava num optimismo epistemológico de cariz prometeico e fáustico; o que dá lógica ao facto de a sua proclamada presciência não se ter limitado ao papel de um ideal regulador; também conduziu a um necessitarismo, que só não se confundia com o determinismo absoluto, porque apelava à praxis, desde que por ela mediada.

Como salientou Rosenzweig (1982), a ideia de causalidade (invocada, tanto pelas filosofias da história, como pela historiografia) só podia ser convincente e operativa se narrasse o passado como quem desenrola um fio temporal contínuo, em que o antes (a causa) determina o depois (o efeito), ordenação que, confessadamente ou não, escondia a teleologia que a estruturava, como se o futuro fosse só um efeito do passado, sendo impossível o contrário. E o optimismo antropológico e epistemológico, que dava seiva ao novo ideal de ciência, alargou-se, no século XVIII, à racionalidade que o tempo histórico estaria a explicitar. Já não se tratava de invocar causas externas: a velha "providência" transmudou-se em "lei", ou em "tendência objectiva", e o princípio da razão suficiente neste outro: todo o real é racional e todo o racional é real. E, se foi a linguagem filosófico-metafísica que, pioneira e sistemicamente, melhor tematizou este último, a verdade é que ele continuará ínsito às diversas traduções cientistas que, sobretudo após as primeiras décadas do século XIX, irão perseguir objectivos análogos.

O facto desta visão se ter tornado dominante (e se ter popularizado através das mais diversas traduções ideológicas) não deve fazer olvidar, porém, que tal hegemonia recebeu várias críticas. Em primeiro lugar, a da reacção romântica contra os seus excessos, atitude que se expressou numa maior valorização da subjectividade, da concretude histórica (Volksgeist), da vontade e sentimento, da organicidade, bem como numa representação mais dramática e trágica do devir humano. É que, quanto a este aspecto, na ideia de progresso foi enxertada a possibilidade da sua degenerescência e decadência. Não por acaso, contra ou corrigindo Condorcet, descobriu-se Vico (Edgar Quinet traduziu a Ciência Nova para francês, enquanto Michelet se encarregou de Herder) e a sua periodização da história segundo o ritmo dos corsi e dos ricorsi.

Esta tendência crítica recebeu um desenvolvimento ainda mais radical em pensadores como Schopenhauer e Eduardo de Hartmann e no anti-historicismo de Nietszche. Com isso, cresceu uma orientação de teor mais pessimista, que levará alguns até às portas do niilismo. Mas, outros tentaram conciliar a herança iluminista com este fundo reactivo, pondo em diálogo as duas posições. Outros, ainda, nas suas críticas ao necessitarismo e ao determinismo, mostraram-se mais abertos à valorização do papel do acaso (Cournot), ou à perspectiva probabilística dos fenómenos naturais e sociais. 
De qualquer modo, a concepção do tempo histórico, fundamentada pelas grandes filosofias do século XVIII e XIX, subsumia estas prevenções, talvez porque o seu necessitarismo, as suas pretensões à apreensão da totalidade, o seu optimismo racionalista e prometeico iam ao encontro das expectativas de uma civilização em processo acelerado de industrialização, urbanização e massificação.

Ora, se a visão necessitarista (e, em alguns casos determinista) era comum à grande maioria das teorias da história, pergunta-se: nesse rio inexorável e (aparentemente) irreversível, movido por um agente colectivo, qual o papel dos indivíduos no condicionamento do seu percurso? Responder exige que se sopese o modo como foram negados ou secundarizados, não só o acaso, mas também a acção dos sujeitos que, pelas suas obras, mais pareciam ter determinado o seu itinerário.

\section{A dimensão épico-trágica do "grande homem"}

É indiscutível que o novo saber sobre o sentido universal da história pretendia fazer crescer o poder do homem sobre a sociedade (que é sempre poder de alguns homens sobre outros homens), desiderato que ilumina o papel que, implícita ou explicitamente, a si mesmo se atribuíam os que se proclamavam como reveladores da verdade, e cuja encarnação suprema se deu na figura do "grande homem" e, em particular, na do "revolucionário". Com efeito, em nenhuma outra experiência a convicção de que o homem é o único construtor da história parecia ser fruto de uma encarnação individualizada. É que, nas revoluções - momentos de aceleração do tempo -, os "revolucionários" irrompem como "grandes homens", epifania que parece mostrar que são eles os grandes artífices da ruptura. Porém, não se deve esquecer que, para as filosofias da história, eles se limitam a dar voz a uma existência colectiva, pelo que não passariam de emanações subjectivas da consciência de um povo, de uma nação, de uma classe, da humanidade, do espírito universal. Ora, se até os protagonistas mais evidentes são reduzidos a meros instrumentos da razão histórica, como conciliar esta contradição, afinal uma das faces da que existia entre o universal e o particular, a necessidade e a liberdade, a dimensão colectiva e abstracta do devir e a acção dos indivíduos?

A resposta teve várias versões, mas todas elas, directa ou indirectamente, apontam para Hegel, que reconheceu o papel do acaso (pondo-o, porém, ao serviço da "astúcia da razão") e o dos "grandes homens", embora para os caracterizar como os indivíduos que, melhor do que os seus contemporâneos, e mesmo sem o pleno controlo sobre os efeitos das suas acções, souberam explicitar e pôr em prática as necessidades objectivas do espírito do tempo (Zeitgeist). Para o filósofo alemão, "tais indivíduos não tinham consciência da Ideia geral que desdobravam enquanto 
perseguiam os objectivos deles .... Mas, ao mesmo tempo, eram homens de pensamento, com apreensão das necessidades da época - o que estava maduro para a colheita. Esta era a verdade autêntica para a sua época e para o seu mundo: a forma que devia seguir-se, por assim dizer, e que já estava engendrada no ventre do tempo.... As individualidades histórico-mundiais - os heróis de uma época - devem portanto ser reconhecidos como os seus filhos de mais ampla visão: as suas acções, as suas palavras, são as melhores desse momento" (Hegel, 1965; Patrick Gardiner, 1984). Sob o impacto desta definição, virá a fixar-se, nas décadas seguintes, a visão do "grande homem" como o medium por excelência da ideia geral de história, não obstante - e numa recuperação dos ensinamentos de Herder - ele ser cada vez mais particularizado como o revelador do carácter específico do seu povo, do seu tempo, e, para algumas correntes que foram ganhando força, da sua raça. Portanto, nele se encontraria concentrado, personificado e prototipificado, tanto o geral como o particular, conquanto numa consubstanciação que podia gerar a ilusão de que a história era um produto da subjectividade e da liberdade absolutas do indivíduo. Contra esta ilusão, as filosofias da história dominantes, com o seu necessitarismo imanente, procuravam demonstrar que só dentro do todo evoluente o papel que lhes tinha sido atribuído ganhava verdadeira luz, pois ele arrastava consigo, em simultâneo, o passado e o futuro: o passado, dado que já antes se teria pressentido, como espera, a sua iminente emergência; o futuro, porque, quando o finalismo histórico o obrigou a sair de cena (o desfecho obrigatório para todos os indivíduos e, por analogia, para todos os povos), os efeitos da sua actividade perdurarão como exempla virtutis, isto é, como fama (August von Cieszkowski, 2002) positiva ou negativa.

Este ideal - que o historiador Justus Moeser já havia antevisto - foi acolhido por outros discípulos de Hegel (Victor Cousin) e, miscegenado com a influência de Herder, por românticos como Gorim, Goerres, Niebhur, entre outros, tornou-se numa caracterização dominante. Porém, a sua mais acabada sistematização - ainda que com fundamentos que pretendiam ser anti-metafísicos - encontra-se no pensamento de Comte e de seus seguidores. Aqui, descontados os sofismas no que toca à idolatria do novo Deus - a humanidade -, ele é equacionado em termos ainda mais deterministas. Mas, apesar das diferenças, tem de concluir-se que todas estas concepções o avaliaram como uma espécie de sujeito não subjectivo, recusando dar-lhe uma auto-suficiência verdadeiramente criadora, condição, aliás, só reivindicada por algum romantismo mais solipsista ou radical. Assim, ao invés da tese voluntarista e individualista de Carlyle (2000), ele seria, não tanto um agente, mas mais um agido, ou melhor, uma personagem-símbolo do espírito colectivo (Sílvio Lima, 1958). Por palavras de Alexandre Herculano - o primeiro grande representante desta definição 
no pensamento português, logo seguido por Oliveira Martins - : "o indivíduo que vai à frente da sua época é a ideia predominante dela, encarnada no homem", pelo que os génios são, tão-somente, "o verbo da ideia, são os intérpretes do género humano - e mais nada" (Herculano, 1986).

Tal leitura parece contraditar o apelo à "fabricação" do tempo histórico contido no optimismo que alentava a mundividência moderna, ilação que, todavia, deve ser completada por esta outra: o convencimento da sua verdade compelia à acção, certeza que era reforçada quando a teoria (ou o programa, ou o plano) era acreditada como sendo um ditame científico (como o será nas várias sociologias e, sobretudo, nos vários marxismos). E seria nesta experiência, alimentada pela crença na translucidez da razão histórica, que a liberdade se fundiria com a necessidade. Assim sendo, a situação do "grande homem" era paradoxal: como mediador, ele actualizava os mais avançados mesmo que, até ele e para ele estivessem escondidos - imperativos da história, os quais, contudo, acabavam por ultrapassá-lo, dada a índole objectiva, universal, colectiva e futurante do devir. Devido ao seu papel mediador, ele não sabia - como mostravam os casos de César e de Napoleão, invocados por Hegel - que os efeitos da sua própria praxis também o estavam a cegar, obscuridade que, para ser alumiada, exigia, como paga, um destino trágico para a sua aventura épica no grande teatro do mundo. Daí, a infelicidade do epílogo da sua existência: ou morrem novos, ou são assassinados, ou são presos, ou são incompreendidos. A epicidade do momento de apogeu mais não é do que o primeiro acto da decadência futura.

\section{III}

\section{A história universal em Oliveira Martins e o papel do "grande homem"}

Quanto aos fundamentos da sua teoria da história, Oliveira Martins, para além de Vico, Herder e Michelet, colheu a lição de Hegel e de Proudhon, a quem, desde os inícios dos anos de 1870, juntou a de Schopenhauer e Eduardo de Hartmann. E este eclectismo fixou-se à volta de algụmas ideias que se manterão até ao fim da sua vida, a saber: a recusa do transcendismo e a centração imanentista da explicação do mundo e da vida; o entendimento do devir como um drama que, no espaço e no tempo, actualizava um princípio metafísico, que tendia para a sua plena realização e se objectivava, evolutiva e organicamente, em sociedades concretas; a impossibilidade das ciências, incluindo as recém-formadas ciências sociais, poderem construir uma explicação radical e total do universo e do devir humano; a necessidade 
de o universal se objectivar na concretude do espírito dos povos em vários níveis, tendo o mais particular uma dimensão subjectiva, logo, biográfica.

\section{A ideia de evolução}

A reflexão sobre o conjunto dos resultados das ciências tinha-lhe mostrado que a sua «tabuada .... é um índice da Evolução», pelo que, interrogar os seus fundamentos e inquirir sobre o sentido (ou não) dos seus resultados devia ser o tema maior da filosofia. De certo modo, análoga preocupação já dominara as especulações de Antero de Quental, aquando da frustrada redacção do Programa dos Trabalhos para as Gerações Novas, e continuará presente nos seus textos filosóficos posteriores (Catroga, 1980). Por outro lado, não se deve esquecer que também os positivistas pós-comtianos aceitavam o evolucionismo, incidindo as divergências nos seus fundamentos e na discussão acerca das modalidades específicas da sua realização nos organismos biológicos e sociais. Como Oliveira Martins não foi filósofo, o seu pensamento, nesta matéria, não se encontra sistematizado; mas, como em alguns passos da sua obra reivindica uma raiz metafísica para o devir - sem a qual a sua «teoria da história universal» (Oliveira Martins, 1884) e a sua concepção historiográfica serão ininteligíveis —, impõe-se captar o seu núcleo forte, integrando-o, porém, no contexto polémico da época.

Em 1881, afirmava: «depois de dissipadas as Ideias hegelianas e de reduzidos ao que valem os dogmas e as banalidades positivistas», floresceu o «realismo metafísico», nascido em Schopenhauer e reformulado por Eduardo de Hartmann (Martins, 1955). Contudo, o ponto de partida inicial do seu ideário foi de inspiração hegeliana (conheceu Hegel através de Charles Rémusat e das traduções francesas de Vera e inglesas de Sibree): o Espírito objectiva-se na natureza e na história, a fim de se elevar à consciência de si, realizando o princípio proudhoniano de Justiça. Com o posterior conhecimento de Schopenhauer e, sobretudo, do ideário de Eduardo de Hartmann, esse princípio transformou-se em Inconsciência, ou melhor, em Força, princípio último que, à maneira do hegelianismo, continuará a necessitar, por uma espontânea necessidade interna, de se exteriorizar como espaço e como tempo, para no homem se assumir, finalmente, como Consciência.

Em resumo: para ele, o dinamismo cósmico não seria mais do que a face fenomenológica de uma Força metafísica, de onde emanariam, necessária, espontânea e auto-suficientemente, todos os fenómenos, embora estes, chocando entre si, pudessem produzir efeitos ocasionais. O Espírito, de fundo hegeliano, torna-se sinónimo de Inconsciente (Hartmann), de Vontade (Schopenhauer), de Alma do Mundo. E estas expressões designam a raiz da Vida, postulada como fonte matricial, imanente ao espaço e ao tempo, mas sempre idêntica a si própria, embora se objective em 
«actos sucessivos» e sob aspectos diversos, «criando, em virtude de um princípio de progresso, ou de expansão, as formas cada vez mais adequadas à expressão da sua indefinida capacidade. Cada ser é por isso uma representação particular da energia universal; e o impulso íntimo que o arrasta e faz progredir, exprime um momento da série de estados reais dessa força imanente no Universo e em cada uma das suas partes» (Martins, 1954).

A compreensão do lugar da história, enquanto saber, só podia ser encontrada dentro do sistema das ciências naturais e, sobretudo, no interior do «quadro sinóptico da classificação dos conhecimentos na esfera dos fenómenos sociais». As ciências sociais ordenavam-se, segundo as regras de Comte, numa sucessão que ia da mais geral à mais complexa, e dividiam-se em três grandes grupos: o da física social (tendo como ciências gerais a antropologia, a mesologia, a crematística); o da biologia social humana ou etnologia (dividida, quanto às ciências gerais, em linguística, mitologia e simbologia); e o da psicologia social (tendo por ciências gerais a nomologia ou teoria das instituições, e a economia). Ora, se se transitar do plano das ciências gerais para as outras possíveis subdivisões do saber (ciências especiais, erudição e artes), descobre-se que a enciclopédia martiniana não contemplava especificamente a história como ciência. Isto explica que, na representação gráfica da classificação, ela somente apareça a envolver as formas de saber (ciências gerais, concretas, artes e erudição) directamente ligadas aos fenómenos da biologia social ou etnologia e da psicologia social (Martins, 1955), não recobrindo, portanto, os da física social. Quer isto dizer que, do ponto de vista ôntico, a história somente emergiu a partir do estádio em que o homem, animal social, acrescentou à sua base antropológico-natural a capacidade de objectivar o Inconsciente, isto é, à maneira de Vico, de criar línguas, mitos, símbolos, instituições, riqueza. Nesta sucessão evolutiva, “o domínio da história" iniciouse, finalmente, na "época em que, sobre os motivos animais e étnicos, aparecem em cena os motivos conscientes, ou melhor, os preceitos da filosofia expressos na legislação, a arte dos estadistas, os cálculos dos políticos, ao lado dos dogmas das religiões e da influência dos sacerdócios" (Martins, II, 1921).

\section{A teoria da história universal e o acaso}

Em sua opinião, as filosofias da história não passavam de um ramo de conhecimento que nasceu para dar resposta ao entendimento das relações «entre o homem, como indivíduo social, e o mundo, como seu habitat». O seu primeiro modelo interpretativo concretizou-se sob os auspícios do providencialismo de Santo Agostinho e foi depois sistematizado por Salviano e, sobretudo, por Bossuet, na época moderna. Porém, sofreu modificações decorrentes da maior secularização da sociedade e 
do crescimento da credibilidade da razão e das ciências, vindo a fixar-se, na modernidade, em duas direcções essenciais: uma, iniciada pelo idealismo místico de Vico, passou pelo idealismo panteísta de Herder e culminou no logicismo hegeliano; a outra, de pendor sensualista, teve em Montesquieu (Esprit des Lois), em Voltaire (Essai sur les Moeurs) e, principalmente, em Condorcet (Esquisse d'un Tableau des Progrès de l'Esprit Humain) os seus máximos expoentes, e caracterizou-se por «assentar abstractamente as leis da filosofia da história, à maneira do que outrora fizera Aristóteles» (Martins, I, 1921).

Dir-se-ia que Hegel tinha excedido esta dicotomia. No entanto, Oliveira Martins, embora pensasse que o dinamismo histórico também constituía um processo agónico de objectivação do Espírito (a que, como se sublinhou, também chamou Força, Inconsciente, Alma, Vontade), contestava a construção logicista e abstracta do sistema hegeliano. A seu ver, e ao contrário do que tinha pensado o filósofo alemão, a história não consistia numa mera «dedução lógica das fases normais do Espírito», mas era «o teatro onde ele, recebendo a influência do temperamento individual, dos caracteres de raça, das condições geográficas e climatológicas, da tradição e de todas as causas exteriores que o obrigam a manifestar-se por diversos modos no tempo e no lugar; o teatro, dizemos, onde o Espírito mais superiormente se revela» (o itálico é nosso). Mas importava ter presente que «o indivíduo humano é um ser incapaz de praticamente o manifestar puro e ideal. Um tal homem teria sido Deus, e não poderia haver mais de um homem assim» (Martins, 1985). Deste modo, achava falaciosa a pretensão de se edificar uma visão universalista da evolução da humanidade em termos exclusivamente científicos ou abstractos. Tal empresa exigia uma omnisciência divina, e as insuficiências de tais concepções não radicavam somente no facto de ainda se ignorar o passado de muitas sociedades primitivas, mas eram inerentes às características da própria história; em vez de ser uma realidade homogénea e síncrona, a aventura humana revelava a existência de civilizações particulares, independentes uma das outras e com ritmos civilizacionais diferentes, pelo que «a noção de uma história universal com solidariedade, relações e sincronismo, entre todas as colmeias humanas dispersas sobre a terra, é uma quimera» (Martins, II, 1957).

A lição de Vico e de Herder, logo, do historicismo romântico, não andava longe desta posição. Martins considerava Vico um «homem verdadeiramente genial» e o iniciador da "ciência da civilização», a partir de alguns princípios que, a seu ver, continuavam válidos: a existência de uma ordem ideal imanente ao. desenvolvimento orgânico das sociedades; o entendimento deste como um processo análogo ao crescimento vegetal; a explicação de cada fenómeno histórico em correlação com a evolução dos estádios mentais das sociedades. Para o discípulo português, 
Vico, ao contrário de Herder, só teria pecado por: não se ter apercebido do «facto primordial das raças» e do «facto secundário da influência mesológica»; por ter recorrido ao conceito de providência para credibilizar a existência de uma ordem ideal na história; e, finalmente, por ter dado uma definição excessivamente necessitarista dos seus ciclos - em que a uma fase ascendente (corso), sucederia, inevitavelmente, uma fase descendente (ricorso) - , não percebendo, assim, que esta também podia resultar do encontro fortuito de séries de fenómenos, génese possível, mas não determinística, de uma decadência irreversível (Martins, I, 1921).

Com todas estas correcções, Martins procurava afirmar que o fundamento metafísico (a Força), que fazia da história o «teatro» da sua processão, só se realizava em povos concretos, inseridos em situações concretas. No livro Raças Humanas e Civilização Primitiva, é explícito acerca dos factores que dão corpo a estas particularizações, a saber: a Força (emanação da «capacidade ingénita das raças»); o Acaso (que desempenha um papel eminente na fenomenologia histórica); e o Progresso (isto é, o destino derradeiro para onde encaminha «essa marcha da civilização através do tempo, avassalando o mundo inteiro» (Martins, I, 1921). E, no ensaio Da natureza e lugar das ciências sociais, posicionou-se inequivocamente em relação às três doutrinas que, em sua opinião, as filosofias da história tinham avançado para explicar o sentido do tempo: a do acaso, a necessitarista e a providencialista (Martins, 1955).

Como se sabe, tanto o providencialismo como as filosofias necessitaristas da história (Kant, Cordorcet, Hegel, Comte) rejeitavam o acaso, e o mesmo acontecia com o providencialista Bossuet; em Portugal, Herculano e, posteriormente, os positivistas também não o aceitavam. Porém, neste campo, Oliveira Martins seguiu Voltaire e Cournot: o fortuito podia definir-se, não como um fenómeno em si, mas como o encontro inoportuno, intempestivo, de duas séries ou sistemas independentes (Martins, 1985). E estes choques imprevisíveis provocavam efeitos tanto nos fenómenos naturais como na vida dos povos e dos indivíduos: foi o caso do terramoto na preparação dos ânimos para a aceitação do jugo do marquês de Pombal; da descoberta das minas de ouro do Brasil; do desastre fatal do filho de D. João II (que terá mudado o curso da história da Península); da derrota de Alcácer-Quibir, originada pela fortuita paranóia do rei (Sílvio Lima, 1958).

Por outras palavras: no campo fenomenológico, o papel do acaso aumentava com a particularização e complicação dos fenómenos, e com o crescimento da incidência da acção voluntária dos indivíduos, que, como Comte já havia defendido, era maior nos fenómenos sociais do que nos naturais. Em consequência, a imprevisibilidade, que não podia confundir-se nem com o desconhecido nem com o incognoscível, constituía um factor de peso na inviabilização de prognósticos cientificamen- 
te demonstrados, porque a previsão científica exigia a recorrência, e os fenómenos históricos, para além de complexos e menos gerais, são irrepetíveis; e seria contraditório fazer-se a prognose do inesperado.

O acaso, contudo, não implicava a queda numa concepção caótica da realidade, pois não constituía uma característica das coisas, mas decorria das relações entre elas. Por outras palavras: o encontro das séries individualizava e dava especificidade empírica aos acontecimentos, facetas que deixavam de ser ilógicas, desde que fossem integradas em totalidades sintéticas e retrospectivas, que a história, metafisicamente fundamentada, poderia idealizar. Isto é, à luz da ordem ideal, ela tinha um sentido inteligível. Em tal perspectiva, os factos, aparentemente caóticos, ganhavam sentido a partir da ideia de finalidade que a razão humana tem de postular, ilação que, aparentemente, parecia coincidir com as teses providencialistas e iluministas. Só que, agora, a chave do telos último do devir histórico não se encontrava «nem nos desígnios duma Providência fenomenalmente activa, nem no princípio de um Progresso indeterminado e indefinido; embora não possa conceber-se o mundo senão como um ser que caminha, e caminhando progride; e por isso mesmo que progride executa uma acção providencial. O progredir, porém, sem determinação ou destino, é tão inconcebível como o colocar o fim providencial numa existência ultraterrestre. A plena existência dos seres é o princípio da sua criação; e assim a manifestação do Espírito consciente na sua plenitude é o princípio do mundo, e a finalidade da história» (Martins, 1985). Em suma: o alfa do universo acabará por coincidir com o omega da história, ou melhor, esta será a concretização, como Consciência, da primordial Força Inconsciente, de onde nasce o movimento e a vida.

Só a subida a uma visão totalizadora permitiria compreender que, apesar, das inevitáveis assimetrias e decadências empíricas das partes, a civilização não deixava de progredir, tese que não constituía uma novidade perante o modo como, tradicionalmente, as filosofias da história tinham tematizado o progresso. Martins reconhecia em Hegel, descontada a abstracção do sistema, «o grande e eterno merecimento» de «ter definitivamente evidenciado a unidade e o progresso da civilização geral». E nele o fim (objectivação do Espírito) também surgia como a concreta consumação da origem, itinerário que possibilitaria perceber que «a civilização, tão absoluta quanto é dado à capacidade natural do homem e às condições de existência que a terra lhe prepara, é um destino real, imanente, que por uma vereda tortuosa, irregular no traço e no leito, erriçada de embaraços fortuitos, diferente sempre, mas sempre dirigida ao fim predestinado, segue como os rios, direito ao mar». Isto é, e como escreveu em As Raças Humanas e a Civilização Primitiva, se «a história é uma viagem, de rumo vário, mas de destino certo», «a humanidade é uma tripu- 
lação. As civilizações, com as suas ideias, as suas forças, os seus meios, as condições da sua existência, são como o barco vogando no oceano, armado mas não imune contra os casos funestos» (Martins, I, 1921).

Tais obstáculos, se invalidavam a crença excessiva no progresso linear e indefinido, também não caíam numa concepção cíclica. É que, ao contrário do que Vico havia sustentado, o ricorso só tinha validade em relação às partes: «se não há ricorso necessário nas civilizações particulares, embora de facto haja quedas fortuitas; se na civilização geral não há ricorso, mas sim um progredir constante, embora nem sempre se progrida correlativamente em todos os órgãos e funções sociais: há, porém, ricorso necessário e demonstrado na existência particular de muitos órgãos da sociedade» (Martins, I, 1921). Consequentemente, seria errada «a ideia de um progredir constante, igual, sem incidentes nem catástrofes. Conceber assim a evolução, quer na história - ou antes, no dinamismo das sociedades humanas -, quer na zoologia ou na cosmogonia, é incorrer num erro: a evolução resulta de uma sucessão de revoluções mais ou menos aparentes» (Martins, II, 1957). E, como o processo histórico não era homogéneo - devido às desiguais capacidades ingénitas entre as raças -, os povos não podiam ser, em termos civilizacionais, contemporâneos uns dos outros. Mesmo dentro de cada povo, por mais civilizado que este fosse, podia existir um sector social atrasado; o que ilustrava a validade da sua tese: cada sociedade tende a reproduzir a escala etnométrica geral no seu próprio interior.

\section{A epopeia dos árias}

Chegados a este ponto, uma pergunta se impõe: de entre todas as raças que se foram ramificando pela terra, qual seria vanguarda e paradigma de civilização? O critério aferidor, se era histórico, tinha, contudo, uma base antropológica, a saber: todas as raças humanas possuíam a mesma aptidão ingénita para criarem línguas, mitos, religiões e elaborarem raciocínios, propriedades que, mais do que a cor da pele, as definiam. Todavia, somente uma delas, a indo-europeia, era portadora, na opinião de Martins que seguia, nesta matéria, visões eurocêntricas como as de Hegel, que muitos pensadores do século XIX irão racializar -, da capacidade seminal para alcançar formas superiores de civilização, isto é, para elaborar construções abstractas e ousar indagar a essência última das coisas, construindo, assim, representações universais do mundo e da vida. E essa aptidão dos indo-europeus estaria inscrita na sua idiossincrasia, «como sementes com que a natureza lhes dotara o braço e o cérebro», e a sua desenvolução dar-se-ia em clara analogia com o princípio da evolução fisiológico-orgânica: os dotes psicológicos das raças seriam «como as sementes que têm em si a virtualidade da germinação e crescimento da planta quando encontra um chão apropriado» (Martins, 
1955). Em consequência, as raças teriam características irredutíveis entre si, o que conduzia a que a miscegenação étnica só fosse frutífera quando caldeava grupos pertencentes a um tronco comum, como a formação dos povos europeus exemplarmente ilustrava. Por isso, a explicação etnológica só era válida para os tempos primordiais, e não para as nações, inevitáveis produtos de misturas. Mas, a capacidade do ponto de partida ditava a superioridade do ponto de chegada.

No fundo, para Oliveira Martins, o principal erro de Hegel, apesar do mérito de ter definido a unidade e o progresso da civilização geral, foi o de não ter compreendido a mecânica do dinamismo social: «que o processo de unidade era a absorção» das raças inferiores pela superior, e que o órgão superior era o indo-europeu. Faltou-lhe afirmar que deste modo a ideia de progresso humano se torna um facto concreto ou histórico»; faltou-lhe, em suma, perceber que existe uma natural hierarquização étnica resultante das diferentes capacidades ingénitas dos povos, e que, por isso, estes transportam em si atávicas potencialidades de futuro, em quantidades também variáveis. E se, para uns, estas chegam «para atingir uma civilização como a europeia» - a civilização-tipo para outros, nem sequer dá para saírem do primeiro estado rudimentar e selvagem (Martins, I, 1921). Com a correcção antropológica proposta, o velho preconceito eurocêntrico, característico das filosofias da história, transformava-se, agora, em arianocentrismo (Ana Leonor Pereira, 1995).

Os dramas da história, afinal, seriam episódios da gesta dos árias na sua propagação e apropriação, raça que «foi confiscando para si as conquistas dos povos que encontrou no seu caminho épico, impondo o seu domínio por toda a parte onde a levou o destino de uma expansão que já hoje abraça o globo inteiro» (Martins, II, 1957). Porém, entre os seus vários subgrupos (os celtas, os germanos, os eslavos), a sua primeira afirmação historicamente relevante veio dos arianos italo-gregos, em consequência de um feliz acaso: o da raça ingenitamente mais dotada ter encontrado o meio mais propício para o desenvolvimento das suas capacidades - o Mediterrâneo. Descendo da Índia, os árias construíram ali civilizações com um grau de universalidade ascendente (Grécia, e depois Roma). Mais concretamente, foi com Roma, ou melhor, com a República, que, pela primeira vez, a organização de uma sociedade terá passado da «esfera primitiva do sangue» para a «esfera positiva do solo» e da nação, ao transitar do estado de agregação natural para o da agregação social, fundada na continuidade do território (Martins, 1953).

E se a síntese com os povos indígenas, ou com outros ramos arianos (celtas, por exemplo), provocou momentâneos retrocessos no seu progredir - a seu ver, isso ocorreu na Idade Média, como defendeu na polémica, de 1873, com Antero de Quental e 
Júlio de Vilhena (Martins et al., 1925) -, a resultante do percurso foi, porém, ascensional, pois dessas fusões nasceram os povos nacionais modernos, alguns dos quais levarão ainda mais longe o universalismo indo-europeu, tornando-o sinónimo de história universal. E, como esta se confundia com a epopeia de um ramo étnico (os árias), a historicidade das outras raças era medida pela sua maior ou menor aptidão para serem assimiladas pela civilização europeia, no seu inexorável caminho ecuménico.

O historiador português acabou por perfilhar uma ideia de história que é simultaneamente filha do idealismo objectivo e do naturalismo organicista, em que o decadentismo das partes é condição necessária para a afirmação do progresso geral, encarnado e movido por um ramo étnico-cultural. Assim sendo, quer por razões de cariz filosófico, quer por ditames de ordem existencial - que se vão acentuando com as suas desilusões políticas e com o impacto do desfecho trágico da vida de grandes amigos (Antero de Quental) -, o seu optimismo só poderá ser compreendido (aliás como o de Antero) dentro do pessimismo, embora este nunca tenha assumido a faceta niilista que as suas influências filosóficas podiam ter desencadeado. De facto, apesar das afinidades com Schopenhauer e, sobretudo, com Eduardo de Hartmann, a filosofia da natureza e a concepção da história universal martinianas não desaguavam no não sentido das coisas e na apologia do suicídio cósmico. Como lembrava em 1881, «ao lado do protesto da minha consciência ponho o protesto da minha razão, porque é absurda a doutrina em que o Universo se condena ao aniquilamento pelo caminho da existência, torturando-se a si próprio sem causa nem motivo para esse viver que seria um escárnio. Se o Nada esteve antes e está depois da Existência universal, essa existência não pode ser uma paixão dolorosa que ninguém impôs ao Universo» (Martins, 1955) e a vida uma paixão inútil.

Todavia, a história não deixava de ser um teatro e um drama, pois, tal como em Hegel, o seu transcurso exigia a finitude e a morte, expressões necessárias da negatividade. Por isso, cada civilização tenderá a parar num certo momento do seu desenvolvimento, quando a sua existência histórica explicitar «o limite máximo da capacidade da melhor das suas raças»; aí, «suceder-lhe-á degradar-se, degenerar até morrer». E, mesmo a raça ariana, com toda a sua vocação universalista, tarde ou cedo, não fugirá a esse destino, "porque o ritmo vital é a condição de tudo o que realmente existe". Só o mundo inteligível ultrapassa os limites da historicidade, porque, como na mundividência greco-romana de fundo platónico, somente "as ideias da razão são reais, absolutas e eternas!» (Martins, I, 1921); remate que, em Martins, ganha coerência à luz da sua sobredeterminação metafísica das teses organicistas e evolucionistas subjacentes à sua teoria da sociedade. 
Manifestando-se a Força Insconsciente como vida nos organismos, e requerendo a sua permanente renovação, a morte seria o «trabalho do negativo», ou melhor, o destino fatal das coisas vivas seria caminharem para a morte ao atingirem a plenitude da existência. E o que era válido para os indivíduos, também o seria para as nações, mesmo para aquelas que, dentro da área europeia, tinham desempenhado o papel de vanguarda. Mas, conquanto a «queda» e o fracasso fossem inerentes à condição humana, nem a extinção de tantos indivíduos e civilizações humanas, nem o sempre possível «aborto da civilização total», nada provariam «contra a exactidão ideal deste destino»; mostravam apenas que, «apesar dos seus dotes, nem os próprios indo-europeus eram capazes de tornar mais reais» os ideais que puderam conceber. E o fechamento da história podia ainda ser ilustrado através de uma hipótese de descentração histórico-cósmica: sendo este mundo, à maneira de Leibniz, tão-só, um dos mundos possíveis, num universo infinito, e sendo «a humanidade no seu todo uma semente, o mundo um torrão, entre miríades de sementes lançadas pelos milhões de mundos que povoam os espaços...., quem pode assegurar que o nosso mundo não está fadado para atingir um limitado número de cultura e aí parar em condições que outros mundos, se pudessem ver-nos, considerariam, permita-se a expressão, chineses [o povo então tido como não histórico]?" (Martins, I, 1921).

Em suma: embora, em termos ideais (Vico, Hegel), a história devesse ser concebida como uma sucessão necessária, a sua objectivação implicava um forte grau de probabilidade, característica que confere ao optimismo ideal de Martins uma tradução fenomenologicamente trágica - a certeza do futuro aparece sempre suspensa da iminente e imprevisível ameaça da degeneração e da morte.

\section{Portugal no destino universal da história}

Se, nos inícios dos anos 70, a interrogação do destino de Portugal feita por Oliveira Martins era inseparável da sua sintonia (ou não) com a objectivação do Espírito a caminho da realização da ideia de Justiça, a crescente naturalização da sua «teoria da história universal» obrigou a que essa pergunta fosse respondida à luz do papel específico que a nação desempenhou (ou que podia vir a desempenhar) na epopeia ariana. Logicamente, esta perspectiva obrigava a que a compreensão da história do povo português fosse feita no contexto mais amplo da civilização ibérica, porque tinha por verdade indiscutível, demonstrada pela antropologia e pela etnologia, que Portugal era, tão-somente, uma «molécula» do «organismo social ibérico», e este, da história universal. Em termos historiográficos, isto queria dizer que «metade da história portuguesa [estava], portanto, escrita na História da Civilização Ibérica» (Martins, 1988), dado que, no terreno antropológico, etnológico e mesológico, a Península podia ser consi- 
derada como um superorganismo, que se foi constituíndo, no decorrer dos séculos, a partir do cruzamento de muitos povos e das respectivas culturas.

Ao contrário do que outros defendiam (W. Humboldt, por exemplo), Oliveira Martins dava uma origem semita aos primitivos habitantes da Ibéria, os quais, por isso, teriam uma grande afinidade com os habitantes da África setentrional, conhecidos por hamitas, como a dolicocefalia, as formas de organização social comuns e a semelhança dos monumentos megalíticos de Espanha e dessa região africana estariam a demonstrar. A desafricanização teria começado com a fusão destes povos com os celtas. Contudo, como Mommsen havia ensinado, foi só a ocupação romana quem, verdadeiramente, «arrancou a Espanha da África para a Europa», fazendo de um povo semi-bárbaro uma nação, logo, «uma reunião de homens congregados por um sistema de instituições fixas e gerais, e unidos, não só por um pensamento moral, mas também por pensamentos de ordem civil, política.... A romanização da Espanha foi o facto capital da história da sociedade peninsular», que perdurará para além da dissolução do seu domínio político. Isto é, se a cristianização veio dar «à Espanha unidade moral, os romanos deram-lhe a unidade social, a língua, a cultura literária e científica»; os godos, por sua vez, limitaram-se a trazer a noção de aristocracia de sangue e de hereditariedade, não conseguindo, porém, extinguir por inteiro os valores antigos; com a invasão sarracena, a tolerância dos novos conquistadores impediu o rompimento substancial com a sociedade visigótica já cristianizada, o que possibilitou a coexistência e até a mescla entre os povos. Para além dos aspectos culturais, essa invasão teve, ao mesmo tempo, um efeito imprevisto, ao suscitar uma reacção militar, de onde nasceu a fragmentação da Península em novas nações, cuja génese, brotando «no seio dos combates na desenvoltura dos acampamentos», lhes doou um carácter, que obedeceu mais à lei da natureza espontânea, do que aos ditames das antigas tradições, romanas ou germânicas (Martins, 1994). E foi neste contexto que nasceu Portugal.

Como consequência destas amálgamas de povos, o português foi-se formando, no fundo, através da mistura de lusitanos e galegos (onde também corria sangue suevo) com os turdetanos do sul (onde corria muito sangue bárbaro). Todavia, se desta nasceram algumas singularidades temperamentais, ela não foi suficiente para o destacar dos outros povos peninsulares, que constituíam, no seu conjunto, um corpo etnológico dotado de caracteres gerais comuns, pelo que não seria correcto falar do português como uma «raça»; ele só se distingue dos outros espanhóis por «traços secundários», residindo a sua especificidade, no terreno étnico, nos efeitos caracteriológicos que resultavam de uma maior participação de sangue celta na nossa índole, demonstrada pela descoberta, nas regiões correspondentes à Lusitânia 
e à Tarroconense, de mais nomes de deuses, pessoas e lugares de origem céltica do que em outras partes da Península. Prova não menos importante encontrar-se-ia, ainda, nas características da psicologia colectiva: "Há no génio português o quer que é de vago e fugitivo, que contrasta com a terminante afirmativa do castelhano; há no heroísmo lusitano uma nobreza que difere da fúria dos nossos vizinhos; há nas nossas letras e no nosso pensamento uma nota profunda ou sentimental, irónica ou meiga, que em vão se buscaria na história da civilização castelhana .... Trágica e ardente sempre, a história espanhola difere da portuguesa, que é mais propriamente épica. [E a matriz desta diferença estaria na] maior influência de sangue celta nas nossas veias, de mistura com o nosso sangue ibérico" (Martins, 1988).

\section{Os quatro ciclos da história de Portugal}

Como Michelet, Oliveira Martins viu a génese da nação sob o modelo fisiológico e organicista, ainda que mediado pela vontade colectiva. Por isso, o percurso do nosso corpo político seria historicamente periodizável em analogia com o dos seres vivos. Na primeira fase, que corresponde à primeira dinastia, a génese da autonomia nacional assentou, basicamente, na vontade dos reis; na segunda, principalmente após a revolução de 1383, ou melhor, depois de Aljubarrota, a nação passou a estar mais solidificada com a emergência de um forte sentimento colectivo que incitou os monarcas a assumirem-se como representantes, órgãos e símbolos de algo que não obedecia a leis de natureza física, pois tinha uma origem de cariz moral (Martins, 1988). Pode dizer-se que, nesta conjuntura, Portugal realizou o conceito martiniano de nação, porque foi o momento épico em que esta alcançou a completa união da sua existência com a sua vontade colectiva: «todas as forças do organismo colectivo se acham equilibradas e todos os homens compenetrados por um pensamento, a que se deve chamar alma nacional». Mesmo os elementos étnicos dominantes na miscegenação foram canalizados para esse equilíbrio, criando-se «um fenómeno, a que também chamaremos síntese da energia colectiva. A nação aparece como um ser não apenas mecânico, como nas primeiras agregações; não somente biológico, como nas épocas de mais complexa e adiantada organização; mas sim humano - isto é, além de vivo, animado por uma ideia». Em termos de Durkheim, teria alcançado o máximo «consenso social», momento igualmente propício à irrupção daqueles que lhe deram consciência e melhor realizaram a sua vocação dentro do percurso da história universal: os «grandes homens», com toda a sua intensidade decivisa e heróica (Martins, 1994).

Em Portugal, este climax foi atingido com a dinastia de Avis. Foi então que, inaugurando uma nova sociedade alentada pelas conquistas a Sul, e pela incorporação de 
novas populações, os portugueses se voltaram para o mar. Só nesse momento a ideia de independência coincidiu com os interesses de toda uma região, e se criou a força colectiva necessária para vencer a atracção centrípeta de Castela, lançando-se o país na aventura das Navegações. Simultaneamente, Oliveira Martins, recorrendo ao paradigma da história de Roma, assinalou este apogeu com o acto em que, como escreveu em Camões, «Os Lusíadas» e a Renascença em Portugal (saído 1872 e revisto em 1891), «D. João I crava o pendão das quinas nas muralhas de Ceuta - essa Cartago portuguesa! O mouro foi para nós como o púnico para o romano. As guerras de Berbéria são também as nossas guerras de África, e Nun'Álvares o Cipião da nova Roma. Depois de Zama, depois de Ceuta, o português e o romano, com a consciência completa da sua missão, atingem a plenitude do génio e do império» (Martins, 1986). Este apogeu foi, porém, o prelúdio do declínio, isto é, da "catástrofe", que vai levar à decadência. É que, com a passagem dos Descobrimentos a Expansão, o misticismo idealista da epopeia alterou-se: «o freire achou-se um piloto, o cavaleiro um mercador .... Uma nação rural, guerreira e piedosa, transformou-se numa grande companhia de comércio acesa em fatalismo cruel» (Martins, 1993).

\section{Morte e decadência: o modelo romano}

Como se viu, segundo todos os organicismos sociais, a doença e a morte são mediações necessárias para o prosseguimento da marcha da evolução. E não deixa de ser igualmente sintomático que, nesta matéria, Oliveira Martins, apesar das suas prevenções, nunca tenha perdido de vista a teoria dos ciclos de Vico, inferida a partir da história de Roma, que invoca, não só quando procura compreender a génese da realidade política chamada nação e os ritmos não rectilíneos da história universal, mas também quando pretende periodizar a nossa história e caracterizar alguns dos seus heróis.

O modelo organicista ajudava-o, ainda, a distinguir entre a ideia de decadência e a de crise. Isto é, se toda a decadência decorria de um estado de crise, esta podia ser, igualmente, como mostrava a biologia, uma manifestação de crescimento, já que a sua eclosão era condição básica para o aparecimento de uma realidade nova. Assim terá acontecido com a crise da dinastia borgunhesa, da qual nasceu, com a revolução de 1383, uma nova sociedade que consolidou Portugal como nação. Aqui, «a crise.... parece ter, para a vida nacional portuguesa, a importância que a natureza dá às crises que determinam a passagem de uns para outros dos seus tipos orgânicos») (Martins, 1988).

Mas, numa outra acepção, a analogia entre as sociedades e os seres vivos indicava que os sinais de decadência são sintomas patológicos, que podem conduzir à dege- 
nerescêcia ou ao definhamento completo. Nesta matéria, Oliveira Martins não inovava, mas, tal como muitos outros intelectuais dos finais do século XIX, recorria a metáforas de origem médica ou tanatológica para melhor expressar a ideia de crise e as expectativas no que toca às possibilidades da sua superação (Catroga, II, 1988). Fosse em nome de um conceito organicista de sociedade, ou a partir de um horizonte filosófico crente na dimensão indefinida do progresso (ou de ambos), a realização do universal condenava a parte à finitude e à morte, depois de cumpridas as funções que lhe eram próprias. Por palavras suas: "A decadência dos povos e a morte dos indivíduos são condições, necessárias ambas, da sua grandeza e da sua existência; e os fenómenos ou sintomas da corrupção colectiva ou da decomposição dos organismos animais, são também apenas a perversão do princípio da vida, no qual se contém a necessidade da morte" (Martins, 1994). Porém, outros factores, de ordem volitiva, ou resultantes da mera interferência de circunstâncias fortuitas, podiam acelerar, retardar ou desviar um caminho que, movido pela matriz étnico-cultural de cada povo, só seria espontâneo e normal se se desenvolvesse numa série absolutamente isolada da dos outros povos, o que, na fase moderna da história, seria impossível.

Com a colonização, ou melhor, com a colonização do Oriente, criaram-se os gérmens da decadência, pelo que, depois da génese e do apogeu, se entrou no terceiro ciclo da história de Portugal. Foi então que «os elementos de vida própria, formados na época anterior, produziram uma colonização à antiga e uma literatura neolatina: nestas duas circunstâncias provámos faltar-nos uma fibra de íntima originalidade nacional. A perversão dos costumes, a vastidão das empresas, o limitado dos nossos meios, os erros políticos, finalmente, condenam-nos à perda da independência» (Martins, 1988). Assim, ao contrário dos que se limitavam a enaltecer os Descobrimentos, o historiador não escamoteava os efeitos perversos que estes acabaram por produzir, alimentados por estas causas essenciais: o individualismo, o jesuitismo e o espírito de conquista. $\mathrm{O}$ individualismo que, nos séculos XIV-XV, «dera os grandes homens», no século XVI, somente gerara «miseráveis que, afectando a grandeza num luxo perdido, pensam que o ouro e a dissolução bastam para criar e manter uma aristocracia»; o jesuitismo, que, nos seus inícios, estava imbuído de uma mística regeneradora, «agora é apenas uma religião de obediência, e uma escola de sistemática perversão; as conquistas foram a empresa que os dois sentimentos anteriores levaram a executar - e agora são apenas a sentina que vaza sobre a Península um ouro corruptor, o estigma da escravidão, a sífilis, o amor da ociosidade, a desordem dos costumes» (Martins, 1994).

Mais concretamente, os povos peninsulares estariam a ser vítimas do papel que, inconscientemente, desempenharam na história universal. Dir-se-ia que o seu apogeu 
criou o embrião da sua queda. De facto, Portugal e a Espanha desempenharam um papel cujos efeitos terão ultrapassado as suas capacidades e os seus próprios interesses, já que, na perspectiva do todo e da evolução histórica, os Descobrimentos tinham inaugurado uma nova fase na mundialização da raça indo-europeia, fazendo do Atlântico o Mediterrâneo da Época Moderna. E, crente na lógica implacável dos mecanismos dessa expansão (integração ou exterminação), Oliveira Martins viu a empresa colonizadora e a subjugação dos povos indígenas em termos análogos aos que, outrora, caracterizaram os primeiros degraus da expansão indo-europeia: "Os latinos, os gregos, os celtas, fizeram na Europa remota o mesmo que nós, espanhóis e portugueses, fizemos modernamente no Brasil e nas Antilhas, o mesmo que os anglo-germânicos fazem em novos dias na América e na Austrália" (Martins, II, 1957).

Esta gesta era apresentada como fruto do «génio peninsular», feito de heroísmo, de idealismo, de desejo de independência, ideais animados pelo fundo místico que impeliu portugueses e espanhóis para a acção (estas características são particularmente sublinhadas nos seus escritos posteriores a 1879). Mas, atingida a plenitude, a grandeza foi tanto mais efémera quanto a acção se mostrava desfasada da realidade nova que ela mesma estava a criar. Daí, a ironia trágica da história: os Descobrimentos, ao acelerarem o desenvolvimento da ciência, do individualismo, da avidez do lucro, e ao socializarem valores como o utilitarismo, contribuíram, indirectamente, para que a mentalidade heróico-religiosa, que os impulsionou, rapidamente se tornasse anacrónica. É que, se o peninsular soube encontrar «no misticismo um fundamento para o seu heroísmo, e fez do amor divino a melhor arma para o seu braço» (Martins, 1994), com o luxo, o dogmatismo inquisitorial e jesuítico, a rapina, tais valores degeneraram em caricatura e transformaram-se em força bloqueadora do progresso, pois eram incompatíveis com a nova mentalidade mercantil. $\mathrm{E}$, perante esta desadequação, a história retirou-lhes o facho da sua vanguarda, para o entregar aos anglo-saxões.

A inaptidão ingénita para criar uma via diferente para a consolidação do seu Império convidava à comparação do destino de Portugal com o de Roma. Já Santo Agostinho havia meditado sobre a história dos homens a partir do impacto da queda da Cidade Eterna. E Vico, na busca de um modelo para os ritmos da sua «ordem ideal», encontrou nos sucessos romanos as fases-tipo que sintetizariam a evolução histórica de todas as civilizações. Por sua vez, Maquiavel, Montesquieu, Beaufort, Gibbon, Niebuhr e o pessimista Mommsen elegeraram-na, ainda, como tema historiográfico, com uma intenção não isenta de analogias em relação ao presente (W. Kreutzer, 1997, a e b). 
Martins também escreveu a sua História da República Romana (1885), obra em que declara colocar-se mais na perspectiva do nomólogo do que na do historiador, precisamente porque procurava encontrar as características-tipo da ordem ideal que pudessem legitimar a comparação. Não admira. Como afirmava em carta a Barros Gomes, acreditava que, «despindo a teoria de Vico do seu simbolismo poético, se encontra aí a chave do problema: isto é, que a evolução da sociedade romana é um tipo» (Martins, 1924), ou melhor, um paradigma, tese que reafirmou em outros textos e explicitou no ensaio Teoria da história universal, reactualizando, assim, os pressupostos clássicos do preceito historia magistra vitae, ao escrever algo que, entre outros, não repugnaria a Tucídides: "os traços essenciais da história romana encontram-se pois em todos os demais povos: assim o naturalista encontra em todas as colmeias o mesmo desenvolvimento orgânico dos mesmos instintos e artes; e como o zoólogo que, ao querer estudar os costumes das abelhas, tem de escolher uma colmeia perfeita e típica, da mesma forma o nomólogo, ao querer estudar o desenvolvimento orgânico das sociedades humanas, escolhe um exemplo perfeito e típico. Esse exemplo é Roma" (Martins, II, 1957; os itálicos são nossos).

De facto, também em Roma seria possível detectar, com toda a nitidez, uma fase formativa e a sua posterior passagem para a República, a que se seguiu um período de expansão e de conquista; com este, veio o poder e o enriquecimento, que criaram a situação anómica que levará ao cesarismo, época de paz e de conciliação, mas que, porém, não conseguirá evitar a queda na autocracia do Império. Em síntese: também aqui as condições de grandeza foram a base da decadência. Roma teve de se expandir pelo Mediterrâneo, desempenhando, assim, um papel crucial na universalização da civilização ariana; porém, com isso, ficou condenada a perder os valores, as instituições e as práticas políticas do seu apogeu anterior, e a não ter capacidade de resposta para os conflitos que a nova situação gerou (Augusto Santos Silva, 1984). Pelo que "o drama português teria reproduzido, à sua escala, este percurso: Vasco da Gama é Eneias, Camões é Virgílio, Ceuta é a Cartago portuguesa; e também conquistou e assimilou outros povos subalternos. Todavia, ao contrário dos romanos, não teve a vis bastante para os reger, devido a causas que, em últimas instâncias, radicavam na influência do elemento céltico na formação do seu temperamento, no fundo, mais propenso à aventura anárquica e ao lirismo poético do que à racionalidade requerida pelas novas formas de organização social e económica" (Machado Pires, 1995). E quando, com a crise, as características do elemento étnico, dominante na miscegenação, surgem à superfície, tal significa que a nação (entidade cimentada por uma vontade colectiva, que solda as diferenças) tende a definhar, para dar voz à nacionalidade, realidade primordial e predominante étnica. Deste modo, o celtismo, ao vir ao cimo, manifestou-se como sebastianismo, fazen- 
do sobreviver algo que se julgava definitivamente extinto: a determinação étnica dos comportamentos nacionais. Daí as célebres palavras de Martins: o sebastianismo é "a prova póstuma da nacionalidade".

Se, como se viu, um novo período da história de Portugal começou, simbolicamente, em 1580, isto significa que o domínio espanhol não terá trazido qualquer alteração substancial ao seu curso descendente, pois constituiria uma espécie de consórcio entre «dois cadáveres». É verdade que a Restauração foi fértil em eclosões de cunho sebástico - a que não foi estranha a pregação jesuítica -, mas a força colectiva que a impulsionou não tinha nada de comum com a vis épica que, libertando o seu povo do determinismo da etnicidade (e da nacionalidade), autonomizou Portugal e o construiu como nação (1383). A queda do poder dos Filipes deveu-se, tão-somente, ao jogo de interesses das potências estrangeiras (Inglaterra, França). Consequentemente, a Restauração não podia ser apreciada como o início do ressurgimento nacional - ideia sugerida no Febo Moniz - , porque a reconquista da independência foi uma ficção: ao domínio espanhol sucedeu o protectorado inglês, ou, na expressão do próprio Oliveira Martins, no Portugal restaurado dominavam «o rei, o jesuíta e o inglês: o sátrapa, o mestre e o judeu. Esta é a trindade augusta que vai reinar em Portugal - uma necrópole» (Martins, 1988). Exceptuando o elogio ao Marquês de Castelo Melhor, considerava que os Braganças continuaram a manter o país numa agonia, que só a descoberta do ouro brasileiro momentaneamente estancou.

Não espanta, deste modo, que, na sua qualificação do percurso degenerescente do País, depois da «Catástrofe» (História de Portugal, Livro V), fizesse seguir «A Decomposição» (História de Portugal, Livro VI), fase que, cronologicamente, recobria o domínio filipino até aos novos reis da dinastia bragantina (1580-1777). Dramaticamente, encerrava-a com o terramoto, símbolo telúrico de uma decadência que parecia estar esquecida sob os faustos do ouro brasileiro e do voluntarismo de Pombal, mas que se acentuará até à Guerra Civil de Oitocentos. Sintomaticamente, designou este quarto período (1777-1834) por «A Anarquia Espontânea» (História de Portugal, Livro VII). Fechar-se-ia aqui a sua periodização da história da nação? É certo que, em 1883, esboçou um outro esquema para um manual destinado ao ensino secundário, em que a divide em cinco épocas, dizendo a quinta respeito aos anos que iam desde o «renascimento nacional pela guerra dos franceses e da revolução vintista até à Guerra Civil e à legislação de Mouzinho da Silveira» (Martins, 1988). Todavia, esta especificação tinha um valor exclusivamente didáctico, já que, do ponto de vista qualitativo, Portugal, sob a Monarquia Constitucional, não só decaía, como se tinha transformado no «Enfermo do Ocidente» (Portugal Contemporâneo, Livro I, Capítulo III). 


\section{A História como arte narrativa e dramática}

Como ficou escrito, na ordem evolutiva, a génese do homem como ser histórico é ininteligível sem as pressuposições dos degraus antecedentes do ser, incluindo a sua dimensão natural, estudada pelas ciências da física social. Porém, como escreveu Martins na Teoria da história universal (1884), a nota diferenciadora entre a animalidade e a historicidade humanas radica, mais concretamente, no «grau de consciência atingido pela sociedade [que] leva à redacção das leis, à definição dos dogmas e à individualização da autoridade colectiva, passando das mãos dos pais para a mão do chefe, do rei .... Podemos, pois, dizer que o período histórico das sociedades corresponde àquele» em que os indivíduos se acham divididos «em governantes $\mathrm{e}$ governados». Só a partir daí nasceu a história: «a personificação simbólica da sociedade traz para o foro nacional as paixões dos indivíduos, e deste facto nasce o carácter dramático da história, os sentimentos de um homem tornam-se paixões de um povo, e vice-versa» (Martins, II, 1957; os itálicos são nossos). Assim se vê que, na linha de Hegel, a história é drama logo no seu próprio ser, porque o seu aparecimento deriva do ímpeto da Força que, em busca da sua plena realização, exige a luta, a finitude e a morte. E esse dramatismo será tanto mais intenso quanto mais individualizada e complexa for a sua manifestação diacrónica.

O campo de estudo da história devia seguir, por conseguinte, o curso da civilização em geral até ao nível das suas expressões mais concretas, complexas (Comte) e heterogéneas (Spencer). Aliás, para Martins, esta gradação reflectir-se-ia nas características do próprio discurso historiográfico: este ganhava contornos tanto mais pessimistas quanto mais a investigação descia da ordem ideal e universal - que aponta para a existência de um sentido optimista - para descrições mais individualizadas, em que o entrecruzamento de acasos e de paixões, próprias da vida subjectiva, leva a uma tonalidade menos épica. Nesta óptica, ganha significado o que ele escreve quando compara o «clima» da sua História da Civilização Ibérica (1879) com o da História de Portugal (1879): o «entusiasmo optimista» que, regra geral, se respira na primeira - de objecto mais geral - parece ser contraditório «com o péssimo e mesquinho carácter que as acções dos homens apresentam» na segunda; tal antítese, contudo, só é «real para o critério abstracto», mas desaparece «quando se aplica o critério histórico», porque, à boa maneira platónica, «toda a boa filosofia nos diz que o homem real é a imagem rude de um homem ideal, que essa imagem vive no mundo inconscientemente, e que todas as acções dos homens, maculadas de defeitos e vícios, obedecem a um sistema de leis, idealmente sublimes. É a verdade que o povo consagrou quando formulou o adágio: Deus escreve direito por linhas tortas» (Martins, 1988; os itálicos são nossos). 
Em síntese: para o nosso historiador, uma visão totalizante do passado seria quimérica, enquanto representação de todos os povos e de todas as nações, ancorada, como pretendiam os positivismos, em induções, tidas por científicas; na sua opinião, essa perspectiva só seria legítima à luz «da adivinhação metafísica» que, de certo modo, impõe «a sua descoberta à realidade». Colocada a questão do saber histórico neste terreno, seria um contra-senso invocar critérios científicos; o caminho correcto estaria na sua compreensão como uma «filosofia-de-história» (sempre discutível como filosofia), isto é, um conhecimento não nomético, porque oriundo «daquele grau e daquela espécie de verdade compatível com especulações de tal natureza» (Martins, II, 1957). É que, no quadro taxinómico martiniano, a descoberta de leis sociais pertenceria à nomologia (termo proposto por Cournot) e não à história.

Mas, o saber histórico também não podia ser confundido com as artes, enquanto técnicas. Estas «encaram o conhecimento sob o ponto de vista utilitário e prático: exemplo, a engenharia, a medicina, a política» (Martins, 1955); ao contrário, a história aspirava a reconstituir a evolução do homem para além dos limites dos conhecimentos empíricos, eruditos, científicos e técnicos. É que, no caso da falta de informações positivas, ele achava legítimo que o historiador usasse a sua mens divinior, dado que, como saber poético, a história era impulsionada pela necessidade de o espírito perscrutar os enigmas do universo, servindo-se, para isso, não só da razão, mas também da «imaginação que vê, adivinha, pressente com um poder intuitivo, unicamente susceptível de reproduzir sinteticamente a realidade das coisas vivas» (Martins, 1955). Também para ele, tal como para Tácito, W. Humboldt e Renan, seria lícito o recurso à suposição e à imaginação.

Como facilmente se conclui, este posicionamento arrastava consigo uma prática historiográfica que não se queria absolutamente escrava do documento. Dir-se-ia que, como propõem algumas correntes actuais, o historiador, a par do documento, podia recorrer a indícios e a hipóteses, ou, por palavras de Oliveira Martins (Elementos de Antropologia, 1880): «a intuição, a adivinhação, hão-de amiúde suprir o que o exame directo não pode mostrar ...; e as probabilidades suprem muitas vezes a falta de provas» (Martins, 1954; os itálicos são nossos). Tal maneira de ver não foi episódica; em 1891, no ensaio Sobre o ensino da história, repetia o que já anteriormente havia escrito: ciência e história são termos que se excluem, porque «a primeira expõe abstractamente o sistema de leis a que obedece um certo corpo de fenómenos reais; a segunda narra concretamente, isto é, em relação ao tempo, a forma por que os factos nos apareceram» (Martins, II, 1957). 
O cariz narrativo (e não nomotético) do seu saber fazia com que a história, sobretudo no seu nível biográfico, se aproximasse de artes literárias «como a poesia, ou a música», ou do romance histórico, género que ele praticou, mas do qual se veio criticamente a distanciar. Mas, se nos ativermos às suas tomadas de posição a este respeito - e não tanto às possíveis releituras que elas hoje podem suscitar -, será um erro pensar que quis reduzir a historiografia à ficção, subsumindo a realidade referenciada na estrutura interna da narrativa. Relembre-se que ele próprio colocou limites à imaginação e à probabilidade no preenchimento dos vazios documentais: ambas teriam de levar em conta que a verosimilhança é «a primeira das nossas exigências intelectuais» (Martins, 1954). Por outro lado, ao contrário das criações artísticas, a história visava alcançar «o conhecimento real das idades passadas» (Martins, 1955). E, em 1891, voltava a esclarecer: "a história há-de ser objectiva, sob pena de as obras do artista não passarem de criações fantásticas do seu espírito. E há-de, por outro lado, assentar sobre a base de um saber solidamente minucioso, de um conhecimento exacto e erudito dos factos e condições reais, sob pena de, em vez de se escrever história, inventarem-se romances" (Martins, 1993). O historiador, para além de artista, devia ser, igualmente, um erudito, um pensador, um crítico, um jurista e um psicólogo (Martins, 1993), e fazer da história uma "arena amplíssima» para narrar o drama da humanidade, dos povos e, sobretudo, dos homens, mas com os «subsídios das ciências e da filosofia», saberes que, reciprocamente, ela também influenciava (Martins, 1955).

Colocada neste terreno interdisciplinar, a estratégia de convencimento dos discursos historiográficos não podia cingir-se à ordem significante e ser totalmente indiferente à argumentação de tipo científico. Em certa medida, no que a este último aspecto diz respeito, Martins viu a ciência como o fruto de um paradigma, isto é, de um cânone, cuja credibilidade se tinha imposto. Logo, numa época «em que a forma científica do saber predomina», também a história tinha de pedir às ciências, «mais ainda do que à filosofia», «as normas que sirvam na execução das suas missões respectivas» (Martins, 1955). E estas mostravam, como sublinhava em 1881, «que há um nexo histórico na influência exercida por cada acontecimento sobre os acontecimentos posteriores. Vê-se e determina-se a relação de causa e efeito, e por momentos chega-se a observar a realização de leis. Nada há porém de permanente e fixo na sucessão das causas e, por isso, se torna impossível de seguir uma dedução sistemática» (Martins, 1955). Esta asserção significa que não excluía, por inteiro, que o conhecimento histórico operasse com leis. Em $O$ Helenismo e a Civilização Cristã (1878) falava mesmo em "ciência da história» e reconhecia que, ao nível dos fenómenos sociais mais genéricos e simples, eram aplicáveis «à história os processos "científicos, a observação e o método». Por exemplo, «dizer que a 
navegação e o comércio marítimo hão-de ocupar os povos que habitem a zona litoral dos continentes», era invocar uma lei elementar da história imposta pelo «simples bom-senso». Mas, foi-se convencendo de que a capacidade de cientificação diminui à medida que aumenta a complexidade dos fenómenos e, com ela, crescem os efeitos da excepção e do acaso, patamares impeditivos de explicações exclusivamente científicas. Não admira, assim, que tenha abandonado a qualificação da história como ciência, reflexo da consolidação da ideia segundo a qual as leis científicas não podiam chegar a uma «definição total dos fenómenos», porque isso implicava que contivessem em si, «o que não contêm, a prova da finalidade do Universo» e «a causa final da história», (Martins, 1955), algo que só podia ser metafisicamente intuído ou imaginado.

Como se viu, o passado devia ser estudado de acordo com os estádios de evolução das sociedades e seus níveis de objectivação gradativa. E, epistemologica e metodologicamente, o saber histórico teria de lhes corresponder. Isto é, quando a história estuda as sociedades na sua fase de «agregado» natural e mecânico, dificilmente pode superar a narração dos factos e a descrição das condições do meio; quando, porém, diz respeito aos fenómenos da sociedade na sua fase orgânica, e a objectivação da Força ganha formas mais conscientes, já pode reconstituir, à Vico, «a concatenação sistemática das instituições, dos costumes, dos movimentos de classes»; por fim, quando o seu objecto diz respeito às encarnações subjectivas, ou melhor, quando visa uma espécie de terceiro nível, aí, o historiador deve ir «buscar aos caracteres e às biografias» o fio dramático que liga as diversas épocas, pois é nessa análise mais microscópica, exemplarmente consubstanciada na vida dos «grandes homens», que a história melhor se revela como teatro (Martins, 1994).

Esta tripla perspectiva já é invocada na História da Civilização Ibérica (1879) e nos Elementos de Antropologia (1880), embora seja na História de Portugal (1879) e, principalmente, no Portugal Contemporâneo (1881) que ela ganha toda a sua espectacularidade. Aqui, o terceiro nível é mais adequadamente narrado sob o signo do drama, num jogo em que personagens-símbolo, acontecimentos, natureza, ordem diegética do tempo constroem a história como uma tragédia, a qual, à maneira hegeliana, se desenrola num «palco», com os seus «cenários», «personagens», «coros», e segundo um plano que, ilusoriamente, os actores também julgam estar a escrever. E, dos três níveis possíveis em que a evolução social poderia ser encarada - repita-se: agregação, organismo, individualização -, a biografia seria o género histórico-literário mais compatível com a onticidade deste último, porque mais apto a captar a objectivação da Força concreta (e subjectiva). Verdadeiramente, só no patamar biográfico a história é, à maneira de Michelet, uma «ressurreição» dos mortos; só neste plano deixa de ser uma gesta anónima e se povoa de rostos; só aí a sua escrita, ao 
captar toda a riqueza da vida humana, desempenha plenamente a sua função social, tornando-se magistra vitae; só aí ela «é uma lição moral.... Apresentar crua e realmente a verdade é o melhor modo de educar, se reconhecermos no homem uma fibra íntima de aspirações ideais e justas, sempre viva, embora mais ou menos obliterada. Conhecer-se a si próprio foi, desde a mais remota Antiguidade, a principal condição da virtude» (Martins, 1988). Deste modo, será correcto concluir que, à maneira romântica e anticientista, a historiografia de Martins é uma autognose, em que o historiador tenta compreender-se, compreendendo o objecto que revela (Eduardo Lourenço).

De tudo isto se pode inferir que o biografismo final de Oliveira Martins - que teve em Os Filhos de D. João I (1891), A Vida de Nun'Álvares (1893) e no incompleto Príncipe Perfeito os seus melhores exemplos - não é somente uma exigência que decorre do facto de a objectivação suprema do Inconsciente encarnar nos «grandes homens»; ele também é uma autonomização de técnicas descritivas já aplicadas em obras anteriores. Compreende-se. Enquanto historiador que pretendia plasmar, literariamente, a verdade sobre o passado, a sua escrita desdobrava-se, um pouco à maneira de Michelet, numa sucessão de quadros, em que a correlação bipolar das personagens - exemplo: D. Miguel versus D. Pedro no Portugal Contemporâneo era envolvida por uma atmosfera cénica, animada pelas projecções simbólicas das paixões que moviam a acção, segundo o ritmo próprio da tragédia. É assim que, na História de Portugal e, principalmente, no Portugal Contemporâneo, encontramos uma galeria de quadros e de retratos que sintetizam os valores morais e as linhas de força que atravessam o drama histórico. Vejam-se, por exemplo, as biografias que Martins aí traça de figuras como D. Pedro IV, Marquês de Saldanha, Duque de Palmela, Mouzinho da Silveira, Passos Manuel, Costa Cabral, Rodrigo da Fonseca Magalhães, Fontes Pereira de Melo, Alexandre Herculano.

O seu biografismo final não constituía, portanto, uma contradição, ou uma abdicação face à sua obra anterior, mas significou, tão-somente, a maior ênfase que colocou, nos últimos anos da sua vida, na análise do terceiro nível. É que, como voltava a relembrar em 1891, a teoria social implicava a existência de vários géneros historiográficos, conforme se tivesse por objecto a sociedade como um «agregado», ou como um «organismo», ou os indivíduos que melhor expressam, sobretudo nos momentos apoteóticos das sociedades, valores colectivos. Exemplificando com palavras suas: "Tanto é história, v.g., o tratado das instituições nacionais que enchem o $3 .^{\circ}$ e $4 .^{\circ}$ volume da História de Portugal, de Herculano, como a pitoresca vida de D. João I, na crónica de Fernão Lopes. Tanto são histórias as biografias de Plutarco, como o Gouvernment Représentatif de Guizot" (Martins, II, 1957; os itálicos são nossos). 
A narrativa martiniana torna certeiras as leituras que têm ressaltado a literariedade da sua escrita, característica que não recobre somente a consabida influência de algumas das suas interpretações e descrições em obras literárias, como é o caso do eco de Portugal Contemporâneo em Os Maias, de Eça de Queirós, e o da História de Portugal, tanto na Ilustre Casa de Ramires como na Mensagem, de Fernando Pessoa. Por outro lado, as análises literárias têm procurado definir o seu estilo: mais poético e dinâmico do que pictórico e descritivo, segundo Moniz Barreto; António José Saraiva encontrou-lhe laivos de parnasianismo; Machado Pires analisou os seus processos estilísticos, retóricos e alegórico-simbólicos, sobretudo na enfatização metafórica da decadência nacional; Isabel de Faria e Albuquerque chamou a atenção para a necessidade de se correlacionar o estudo da narrativa martiniana com os preceitos do romance realista, de modo a saber-se até que ponto esta corrente estética influiu a sua escrita e deu eventuais achegas «para a sua génese, construção, elaboração de personagens, montagem de ambientes, óptica e finalidade do autor», sugestão que tem a sua razão de ser. Dado o frequente recurso à «imaginação» e à «poética», a escrita de Martins corporiza-se na «utilização da linguagem com outras funções para além da simples afirmativa, com inúmeras recorrências às funções apelativa e poética», feitas com a intenção de impressionar e prender o leitor, táctica de sedução que coloca «o artifício literário ao serviço da pedagogia, da instrução; e conduzir o conhecimento pela insinuação emotiva, sensorial e imagética, é uma arte» (Isabel de Faria e Albuquerque, 1988).

\section{Biografia e apogeu histórico}

A eleição da temática biográfica específica apareceu-lhe inseparável do que acreditava ser o sentido da história de Portugal dentro da história universal. E, à luz da sua concepção sobre os ritmos daquela, tinha por certo que os períodos de apogeu foram sempre os mais propícios ao aparecimento de "grandes homens". Ora, isto não implicava qualquer negação das análises historiográficas que têm por objecto outros graus de objectivação do devir, pelo que não existe qualquer solução de continuidade entre, por exemplo, as obras históricas de Martins dos finais da década de 1870 e inícios dos anos 1880 e as suas biografias posteriores (como não existia entre Herculano, Guizot, ou Plutarco). Mas, a escolha de Camões ou dos filhos de D. João I, de D. Nuno Álvares, ou de D. João II teve muito a ver com o período histórico que sintetizavam. Por outro lado, ao nível dos campos de observação, a biografia era recomendada por apreender melhor o ritmo dramático da história. É que, enquanto biógrafo, o historiador podia actuar como um perscrutador de almas, ou melhor, como um psicólogo que, a pretexto da análise de uma personagem-símbolo, captava o âmago da personalidade do «grande homem», aí onde melhor se reve- 
la o «Inconsciente na Consciência», a «Eternidade na Vida» e o «Universo no Indivíduo» (Martins, 1986).

O herói supremo tende, assim, a coincidir com os fastos da nação. É no momento em que «a árvore nacional rebenta e dá frutos» e «o génio colectivo» já se «encontra definido nas consciências», que a ordem ideal da história «encarna, desce ao seio dos indivíduos privilegiados: e dessa forma, adquirindo o que quer que é de forte que só no coração do homem existe, actua de um modo decisivo e heróico». Por isso, concluía Martins em 1879, «todas as grandes épocas das nações se afirmam por uma plêiade de grandes homens em cujos actos e pensamentos o historiador encontra sempre o sistema das ideias nacionais, anteriormente elaboradas de um modo colectivo, actualmente expressas de um modo individual». E é neste terceiro nível concreto que as explicações do passado perdem o seu cariz anónimo: «tudo agora é pessoal; e na tragédia histórica, preludiada por coros numerosos, ouvemse já as vozes das personagens» (Martins, 1994, os itálicos são nossos).

A biografia representa, portanto, a personalização máxima da análise histórica. Como sublinhava em Os Filhos de D. João I, sob a explícita égide de Plutarco, «a história tem nos caracteres, como a pintura do retrato, o seu terreno de eleição», sendo esta a perspectiva em que ela mais se aproxima da arte. O maior relevo que, neste plano, se podia dar à intuição e à empatia permitiria alcançar, em sua opinião, «aquela verdade que os escritores críticos em vão pretendiam atingir com a análise dos textos e dos diplomas, e com o estudo aturado das instituições, das classes e de todos os elementos sociais colectivamente obscuros» (Martins, 1993), porque, em certa medida, o biografado, enquanto «grande homem», constituía uma espécie de mónade em que a alma colectiva se reflectia. Partindo da parte também se poderia compreender o todo, pois «o herói vale pela soma de espírito nacional ou colectivo que encarnou nele, e num momento os heróis consubstanciam a totalidade desse espírito» (Martins, 1994; os itálicos são nossos).

Não é este o lugar apropriado para pormenorizar as várias nuances e tipos de herói (positivos e negativos) que se encontram na obra martiniana. Tal tarefa requereria um esmiuçamento interno dos textos e a sua consequente comparação. De qualquer maneira, parece indiscutível que a sua teoria do «grande homem» se inscrevia numa concepção que, entre nós, Herculano havia perfilhado, tendo-se tornado dominante, sob a influência directa ou indirecta de Comte e de seus discípulos, a partir da década de 1870. E isto não obstante as diferenças de fundamentos e de objectivos ideológicos entre os vários autores. Em todos, porém, o «grande homem» aparece como o revelador do sentido inconsciente do tempo, como uma espécie de mediador de ideias 
e acções que, contudo, acabavam por ultrapassá-lo. Portanto, caber-lhe-ia a missão de ser o suplemento subjectivo da alma do Inconsciente. Em tal horizonte, ele era, sobretudo, o representive man de uma época, no trabalho de concretização de ideias e ideais eternos, base platónica do velho preceito: historia magistra vitae.

No cume da sua hagiografia cívica, Martins colocou os filhos de D. João I, porque reactualizadores de alguns dos ideais-tipo que nortearam a vontade colectiva da nação portuguesa no seu período de apogeu: ao dar guarida ao mito da «escola de Sagres», D. Henrique surge-lhe animado pelo sentido inconsciente da história, expressando a heroicidade activa, temerária e tenaz (que Oliveira Martins compara com Hércules, Alexandre e Cipião), e em que se aliava a fé e a sede do lucro; D. Duarte, «hesitante e dúbio», encarnava o perfil do «literato»; $\mathrm{D}$. Fernando, o tipo de herói-mártir, símbolo da passividade e do desprendimento cristão; e D. Pedro, o Hamlet português «fleumaticamente estóico», é elevado a expressão da atitude reflexiva, ponderada, que procura pesar as consequências positivas e negativas da acção, e que Martins integra numa tradição de realismo e de bom-senso políticos, posteriormente retomada por Pombal e por Mouzinho da Silveira. Por sua vez, D. João II, o «maior homem que Portugal, talvez, gerou», significa a conseguida emergência, entre nós, da «razão de Estado» nos negócios públicos (Sérgio Campos Matos, 1992). Como se vê, tudo figuras que irromperam do período áureo da nação portuguesa.

Com isto, pretender-se-á negar que o biografismo da última fase de Oliveira Martins também foi um refúgio para os seus derradeiros desenganos políticos, em que o convívio com os maiores do passado aparece como alternativa à mediocridade contemporânea? As biografias não representavam, também, através do enaltecimento de um período de grandeza, uma resposta historicista a uma época - discussão da «questão-colonial», o Ultimatum, a crise financeira — que parecia conduzir o país para uma decadência irreversível? Responder afirmativamente a estas perguntas em termos exclusivos seria não levar em conta a justificação teórica que ele mesmo fez sobre as suas capacidades e virtudes. Porém, não reconhecer que a conjuntura condicionou a ênfase que lhe conferiu, seria olvidar que, para ele, a história, enquanto saber, só valia pelos efeitos morais que podia suscitar, e a biografia era o género historiográfico que melhor cumpria essa função, como o aparecimento de revistas como o Plutarco Português (1881), ou de colecções como a que Latino Coelho escreveu sob a epígrafe Galeria de Varões Ilustres de Portugal, comprovam.

O valor literário daqueles estudos e a conjuntura em que eles apareceram deram-lhes um sucesso imediato. Eça de Queirós, a propósito de Os Filhos de D. João I (1891) e de A Vida de Nun'Álvares (1893), declarou mesmo que tais obras ajudavam a reapor- 
tuguesar Portugal. Mas também criticou o amigo, chamando-lhe a atenção para a existência de evidentes analogias entre as personagens históricas e algumas figuras contemporâneas, como a do Conde Andeiro com a de um dos grandes adversários políticos de Martins, o jornalista Mariano de Carvalho. Simultaneamente, tem-se visto na caracterização moral de Nuno Álvares Pereira o retrato psíquico do próprio autor (António Sardinha), ou, o que é mais provável, a consubstanciação de uma heroicidade ética, dramaticamente encarnada no seu grande amigo Antero de Quental. Seja como for, não deve surpreender este recurso à analogia, prática que se encontra em toda a sua obra. É que esta podia ser justificada pelo facto de os indivíduos concretos veicularem ideias-tipo, limitadas e fixas, mas passíveis de serem compartilhadas por outros indivíduos, em outros tempos e em outras situações. Por outro lado, se o recurso à imaginação e à intuição, e, portanto, à suposição e ao verosímil, tinha uma aplicação geral, a sua utilização seria ainda mais pertinente na análise da psicologia das personagens-símbolo. O que facilitava, mesmo inconscientemente, a projecção de juízos de valor, fazendo do biografismo histórico uma narrativa próxima do romance.

\section{BIBLIOGRAFIA}

Albuquerque, Isabel de Faria e, "Introdução" in J. P. Oliveira Martins, História de Portugal Lisboa, IN-CM, 1988.

Arendt, Hannah, Between past and present, New York, The Viking Press, 1968.

Aristóteles, Poética. Tradução, prefácio, introdução, comentário e apêndices de Erodoto de Sousa, 6. ${ }^{a}$ ed., Lisboa, Imprensa Nacional - Casa da Moeda, 200.

Benavides Lucas, Manuel, Filosofías de la historia, Madrid, Editorial Sínteses, 1994.

BENVENISTE, É. Le vocabulaire des instituitions Indo-europénnes II: pouvoir, droit, religion, Paris, 1969.

Buchez, Ph. J., Introduction à la science de l'histoire, vol. 1, Paris, Guillaumin, Éditeur, 1842.

CARlyle, Tomás, Los Héroes. El culto de los héroes y lo heroico en la historia, México, Editorial Porrúa, 2000.

Catroga, Fernando, “A ideia de evolução em Antero de Quental”, in Biblos, vol. 56, 1980.

CAtroga, Fernando, A Militância laica e a descristianização da morte em Portugal, vol. 2, Coimbra, Universidade de Coimbra, 1988.

Catroga, Fernando, "A história e as ciências sociais em Oliveira Martins", in Luís Reis Torgal et al., História da história em Portugal, Sécs. XIX-XX Lisboa, Circulo de Leitores, 1996.

CAtroga, Fernando, Memória, história e historiografia, Coimbra, Quarteto, 2001.

Catroga, Fernando, Caminhos do fim da história, Coimbra, Quarteto Editora, 2003.

CHÂTELET, François, La Naissance de l'histoire, Paris, Seuil, 1968. 
Cieszkowski, August von, Prolegómenos a la historiosofia, Salamanca, Ediciones Universidad de Salamanca, 2002.

Collingwood, R. G., A Ideia de história, Lisboa, Presença, s.d.

CONDORCET, Esquisse d'un tableau historique des progrès de l'esprit humain, Paris, Boivin et Éditeurs, 1933.

GARDINER, Patrick, Teorias de história, 3ª ed., Lisboa, F.C.G., 1984.

Gooch, George, Historia y historiadores en el siglo XIX, México, FCE, 1977.

Hegel, La Raison dans l'histoire, Paris, UGE, 1965.

Herculano, Alexandre, Opúsculos, vol. 5, Lisboa, Presença, 1986.

Heródoto, Histórias, Liv. 1. ${ }^{\circ}$ Lisboa, Edições 70, 1994.

KANT, Antropologia en sentido pragmatico, Madrid, Alianza Editorial, 1991.

Koselleck, Reinhart, Futuro pasado. Para una semántica de los tiempos historicos, Barcelona, Ediciones Paidós, 1993.

Kreutzer, W., "A História romana em Mommsen e Oliveira Martins - dois estilos", in Ludwig Scheidl (coord.), Estudos sobre cultura e literatura portuguesa e alemã, Coimbra, Minerva, 1997a.

KREutzer, W., "Oliveira Martins e o pensamento alemão da sua época", in Ludwig Scheidl (coord.), Estudos sobre cultura e literatura portuguesa e alemã, Coimbra, Minerva, 1997b.

Lima, Sílvio, O Determinismo, o acaso e a previsão na história, $3^{\mathrm{a}}$ ed. actualizada, Coimbra, Coimbra Editora, 1958.

LöwITH, Karl, O Sentido da história, Lisboa, Edições 70, 1990.

LozAno, Jorge, El Discurso histórico, $2^{\mathrm{a}}$ ed., Madrid, Alianza Editorial, 1994.

MALTER, Rudolf, "Schiller como filósofo de la historia", J. Ch. Schiller, Escritos de filosofia de la historia, Murcia, Universidad de Murcia, 1991.

Marramao, Giacomo, Poder y secularización, Barcelona, Ediciones Península, 1989.

MARTINS, J. P. de Oliveira, "Theoria da história universal", in Taboas de chronologia e geographia historica, Lisboa, 1884.

Martins, J. P. de Oliveira, As Raças humanas e a civilização primitiva, 2 vols., Lisboa, Parceria António Maria Pereira, 1921.

Martins, J. P. de Oliveira et al., A Idade-Média na história da civilização, Lisboa, Parceria António Maria Pereira, 1925.

Martins, J. P. de Oliveira, Febo Moniz, Lisboa, Guimarães Editores, 1952.

Martins, J. P. de Oliveira, Portugal Contemporâneo, 3 vols., Lisboa, Guimarães Editores, 1953.

MARTINS, J. P. de Oliveira, Elementos de antropologia, Lisboa, Guimarães Editores, 1954.

MARTINS, J. P. de Oliveira, Literatura e filosofia, Lisboa, Guimarães Editores, 1955.

Martins, J. P. de Oliveira, Política e história, 2 vols., Lisboa, Guimarães Editores, 1957. 
Martins, J. P. de Oliveira, Alexandre Herculano, Lisboa, Livros Horizonte, 1970.

Martins, J. P. de Oliveira, O Helenismo e a civilização cristã, Lisboa, Guimarães Editores, 1985.

Martins, J. P. de Oliveira, Camões, Os Lusíadas e a Renascença, Lisboa, Guimarães Editores, 1986.

MARTINS, J. P. de Oliveira, História da república romana, 2 vols., Lisboa, Guimarães Editores, 1987.

Martins, J. P. de Oliveira, História de Portugal, Lisboa, IN-CM, 1988.

Martins, J. P. de Oliveira, Os Filhos de D. João I, Lisboa, Guimarães Editores, 1993.

MARTINS, J. P. de Oliveira, História da civilização ibérica, Lisboa, Guimarães Editores, 1994.

Matos, Sérgio Campos, "História, positivismo e função dos grandes homens", in Penélope, vol. 8, 1992.

Matos, Sérgio Campos, "Na génese da teoria do herói em Oliveira Martins", in Estudos em homenagem a Jorge Borges de Macedo, Lisboa, INIC, 1992.

Mosès, Stéphane, L'Ange de l'histoire. Rosenzweig, Benjamin, Scholem, Paris, Seuil, 1992.

Pereira, Ana Leonor, "A teoria da história universal de Oliveira Martins", in Actas do Congresso Internacional sobre Oliveira Martins, Coimbra, 28-30 Abril de 1995 (no prelo).

PIRES, António Machado, "Oliveira Martins e as raízes etnogénicas do povo português", in Actas do Congresso Internacional sobre Oliveira Martins, Coimbra, 28-30 Abril de 1995 (no prelo).

Pomian, Krzysztof, L'Ordre du temps, Paris, Gallimard, 1984.

RosenzWeIG, Franz, L'Étoile de la rédemption, Paris, Esprit, 1982.

Santo Mazzarino, Il Pensiero storico classico, vol. 3, Editora Laterza, 1983.

SCHELling, Las Edades del mundo, Madrid, Ediciones Akal, 2002.

SCHILLER, Friedrich von, Escritos de filosofía de la historia, Murcia, Universidad de Murcia, 1991.

SILVA, Augusto Santos, "Morte, mediação, história. Uma viagem tanatológica ao pensamento de Oliveira Martins, Revista de História Económica e Social, vol. 14, 1984.

Whitrow, El Tiempo en la historia, Barcelona, Editorial Crítica, 1990. 


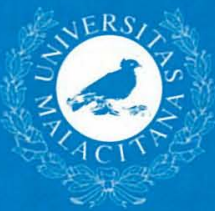

